\title{
Ni-Co Mineralization in the Intex Laterite Deposit, Mindoro, Philippines
}

\author{
Carmela Alen J. Tupaz ${ }^{1, *}$, Yasushi Watanabe ${ }^{1} \mathbb{D}$, Kenzo Sanematsu ${ }^{2}$, Takuya Echigo ${ }^{1}$, \\ Carlo Arcilla ${ }^{3}$ and Cherisse Ferrer ${ }^{4}$ \\ 1 Graduate School of International Resource Sciences, Akita University, Akita 010-0852, Japan; \\ y-watanabe@gipc.akita-u.ac.jp (Y.W.); echigo@gipc.akita-u.ac.jp (T.E.) \\ 2 Geological Survey of Japan, National Institute of Advanced Industrial Science and Technology (AIST), \\ Tsukuba 305-8567, Ibaraki, Japan; k-sanematsu@aist.go.jp \\ 3 Department of Science and Technology, Philippine Nuclear Research Institute, Quezon, Manila 1101, \\ Philippines; caloy.arcilla@gmail.com \\ 4 Century Peak Metal Holdings Corporation, Makati, Metro Manila 1227, Philippines; \\ cherisse.ferrer@gmail.com \\ * Correspondence: carmelaalen.tupaz@gmail.com; Tel.: +81-080-1681-5396
}

Received: 18 May 2020; Accepted: 25 June 2020; Published: 27 June 2020

\begin{abstract}
The Intex laterite deposit in Mindoro, Philippines is derived from the weathering of the ultramafic rocks under a tropical climate. This study investigates the several types of serpentines and the effect of the degree of chemical weathering of ultramafic rocks and laterites on the enrichment of $\mathrm{Ni}$ in the deposit. The five types of serpentines are differentiated based on their textural features and Raman spectral data. Type I, type II, type III, and type IV serpentines contain a low amount of $\mathrm{NiO}$ (average $0.15 \mathrm{wt} \%$ ), and their formation is linked to the previous exhumation of the ultramafic body. Conversely, type $\mathrm{V}$ serpentines show the highest $\mathrm{NiO}$ contents (average $1.42 \mathrm{wt} \%$ ) and have the composition of serpentine-like garnierites, indicating a supergene origin. In the limonite horizon, goethite is the main ore mineral and shows high $\mathrm{NiO}$ contents of up to $1.68 \mathrm{wt} \%$, whereas the Mn-oxyhydroxides (i.e., asbolane and lithiophorite-asbolane intermediate) display substantial amounts of $\mathrm{CoO}$ (up to $11.3 \mathrm{wt} \%$ ) and $\mathrm{NiO}$ (up to $15.6 \mathrm{wt} \%$ ). The Ultramafic Index of Alteration (UMIA) and Index of Lateritization (IOL) are used to characterize the different stages of weathering of rocks and laterites. The calculated index values correspond to a less advanced stage of weathering of the Intex laterites compared with the Berong laterites. The Berong deposit is a Ni-Co laterite deposit in the Philippines, which is formed from the weathering of the serpentinized peridotite. The less extreme degree of weathering of the Intex laterites indicates less advanced leaching, and thereby the re-distribution of $\mathrm{Ni}, \mathrm{Si}$, and $\mathrm{Mg}$ from the limonite towards the saprolite horizon may have resulted in the poor precipitation of talc-like (kerolite-pimelite) and sepiolite-like (sepiolite-falcondoite) phases in the studied saprolite horizon. Nickel in the Intex deposit has undergone supergene enrichment similar to other humid tropical laterite deposits.
\end{abstract}

Keywords: Ni laterite; serpentine; goethite; asbolane; lithiophorite-asbolane intermediate; weathering, Ultramafic Index of Alteration; Index of Lateritization

\section{Introduction}

Nickel laterite deposits are formed from chemical weathering of ultramafic rocks and contain a significant amount of $\mathrm{Ni}$, and to some extent, $\mathrm{Co}$ and $\mathrm{Sc}$ [1-4]. Most Ni laterite deposits occur in the present humid tropics, and tectonically active collision zones, including New Caledonia, Indonesia, the Philippines, and Cuba, but some are situated in cratonic areas in Australia, Brazil, and West 
Africa [5]. Nickel laterite deposits are commonly divided into three types based on the main Ni hosting minerals such as oxide deposits, hydrous Mg silicates, and clay silicate deposits [6-8]. Each of these categories has implications on the assessment of resource and mineral processing [1,9]. A typical Ni laterite profile consists from the bottom to top: (i) the unaltered or serpentinized ultramafic rocks, (ii) the saprolite horizon, and (iii) the limonite horizon. This profile is often covered by goethite-rich ferricrete [10].

An increasing number of studies focus on the distribution of Ni, Co, Rare Earth Elements (REE), Sc and platinum group of elements (PGE) in laterites developed above serpentinite or peridotite bedrock. The composition and textures of garnierites in the Falcondo Ni-laterite deposit reveal variable Ni contents as a result of recurrent changes in the physical-chemical conditions during its formation [11]. The limonite zones in the Wingellina laterite deposit mainly consist of Fe- and Mn-hydroxides, which show high amounts of $\mathrm{Co}$ and $\mathrm{Ni}$ [12]. The associated zones of accumulation of the critical metals (REE, Sc, and PGE) are investigated in Ni laterites from Cuba and the Dominican Republic [13]. Earlier work reported that understanding the sorption mechanism of $\mathrm{Ni}$ in the limonite horizon, $\mathrm{pH}$ conditions, and soil porosity gives further insight into the mobility of Ni within the laterite profiles [14]. Another study investigated the $\mathrm{Ni}$ content of laterites with contrasting mineralogy and crystallinity to understand the enrichment or depletion of Ni upon weathering [15]. Recent work utilized geochemical transport modeling to explain the conditions and processes crucial for Ni mineralization [16]. Despite the numerous works towards understanding the behavior of $\mathrm{Ni}$ in laterites, there is a gap in the knowledge concerning the behavior of $\mathrm{Ni}$ in serpentine in the bedrock and saprolite horizon [17-20].

This study investigates the different types of serpentine found in the bedrock and the saprolite horizon. The chemistry and textures of the serpentines are used to determine the spatial relations between the previous serpentinization and the Ni-bearing serpentines in the saprolite horizon. Emphasis is also placed on examining the main Co-hosting minerals in the limonite horizon of the Intex deposit. Based on the mineralogical and geochemical studies of the studied deposit, this work explores the effect of the degree of chemical weathering of ultramafic rocks and laterites on the enrichment of $\mathrm{Ni}$ in the profiles. Two weathering indexes, namely Ultramafic Index of Lateritization (UMIA) and Index of Lateritization (IOL), are utilized to show the degree of chemical weathering of rocks and laterites in the Intex deposit. We then compare the index results of this study with another tropical laterite deposit, which is the Berong Ni-Co laterite deposit in Palawan, Philippines.

\section{Geological Setting and Topographic Features}

The Mindoro island is situated in the western-central Philippines (Figure 1a): it exhibits the imprints of the arc-continent collision event during Miocene involving the Palawan Continental Block (PCB) and the Philippine Mobile Belt (PMB) [21]. There are opposing suggestions as to whether the whole island is continentally derived [22-24] or only the southwest portion is associated with Palawan [25-27]. The Mindoro island is separated into two blocks: (i) the southwest block, which is comparable to continental-derived PCB, and (ii) the northeast block, which has PMB island-arc affinity $[25,27]$. The two blocks are separated by the northwest-southeast steeply dipping lithospheric boundary, known as the Mindoro Suture Zone, which is cut by the more recent transcurrent fault; East Mindoro Fault Zone [27].

Three ophiolite belts are found in the Mindoro Suture Zone; Cretaceous Manyan Complex, Eocene Puerto Galera Complex, and mid-Oligocene Amnay Complex (Figure 1b) [23,28,29]. The multiphase collisions that occurred from Early to Middle Miocene along this suture zone result in the exposure of the various ophiolites in the island [30,31]. 


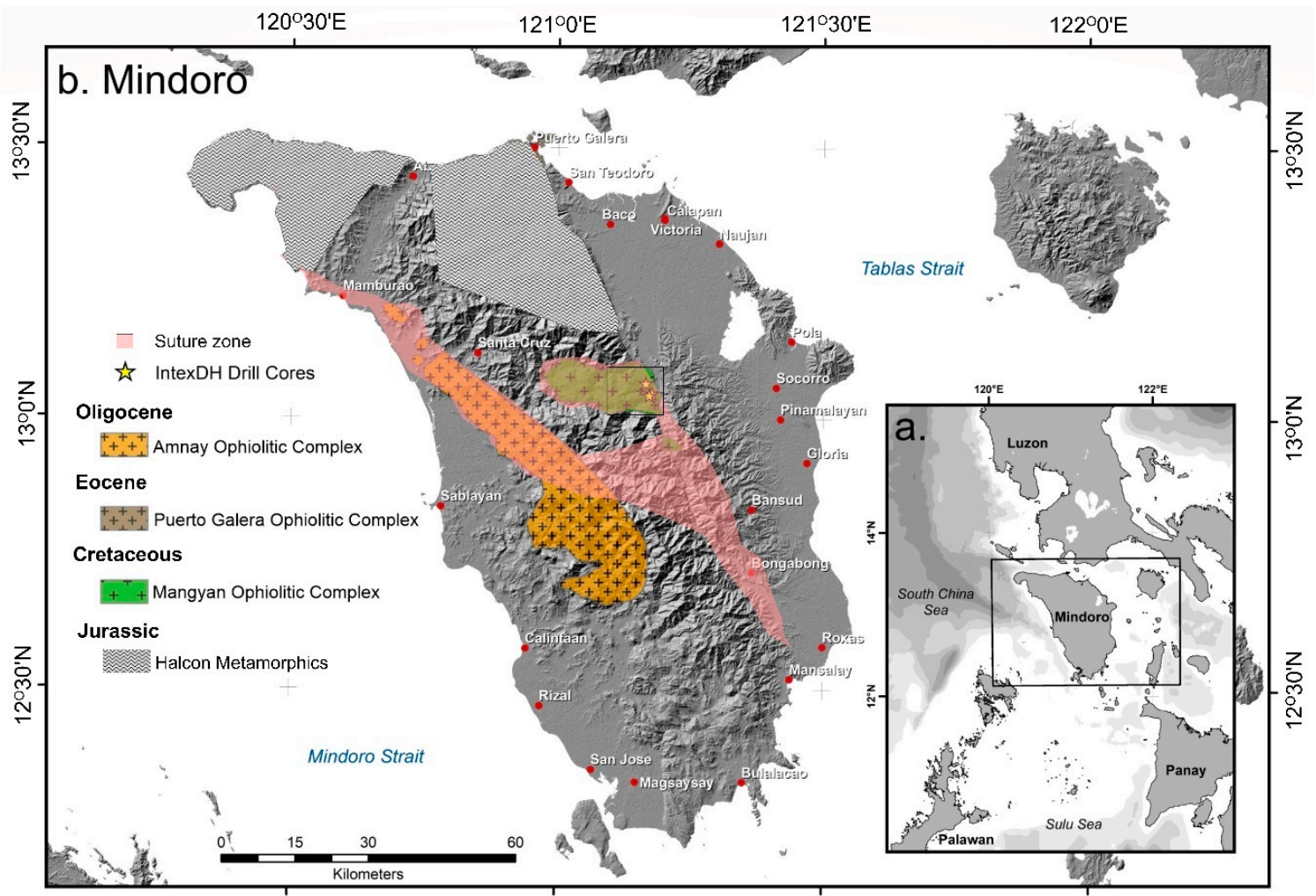

$120^{\circ} 30^{\prime} \mathrm{E}$

$121^{\circ} 0^{\prime} \mathrm{E}$

$121^{\circ} 30^{\prime} \mathrm{E}$

$122^{\circ} 0^{\prime} \mathrm{E}$

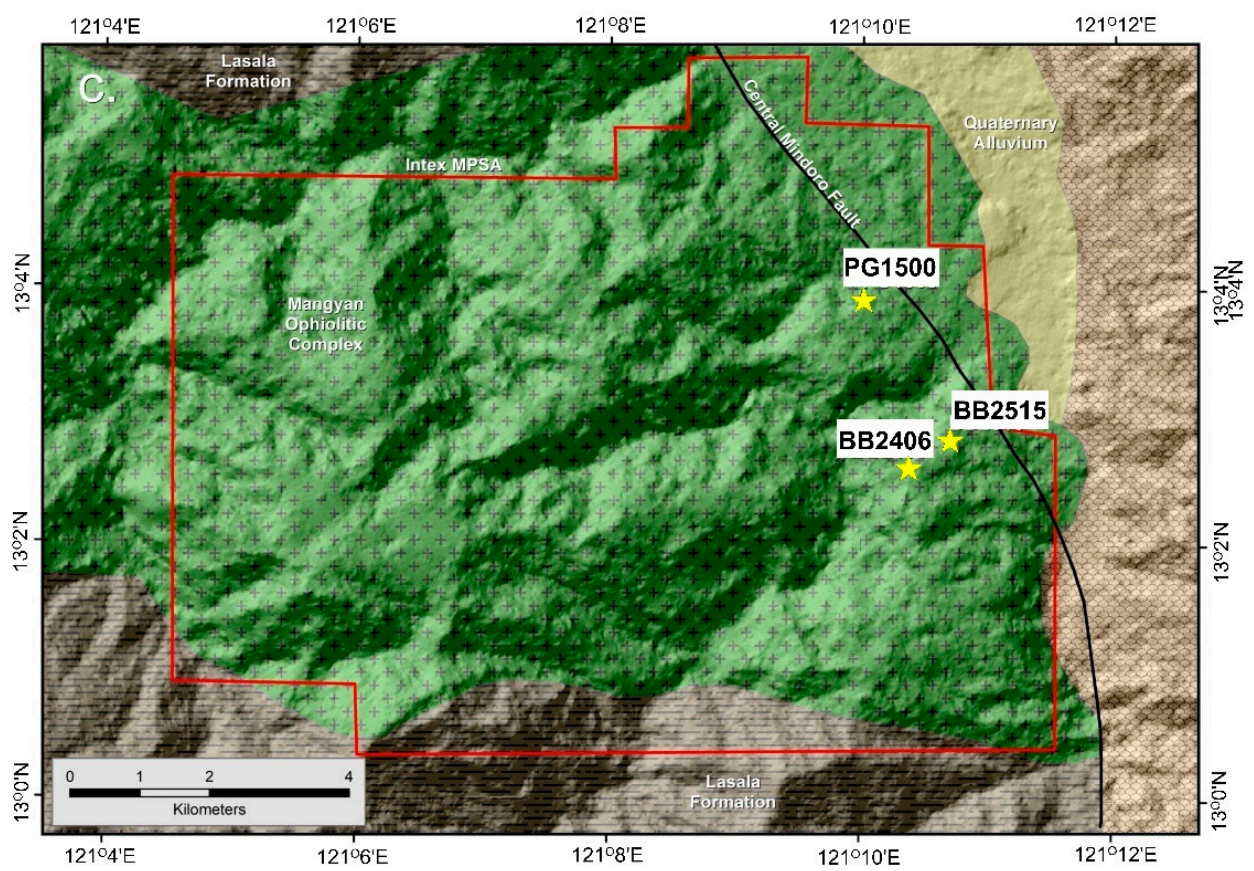

Figure 1. Location map of (a) Mindoro (b) ophiolitic complexes on the island and (c) studied drill cores.

In northwestern Mindoro, the basement rocks are composed of metamorphic rocks and minor amounts of ophiolitic fragments of the Mangyan ophiolitic complex, which are designated as the Halcon Metamorphics [32,33]. The Halcon Metamorphics consist mainly of chlorite, graphite schist, quartz mica with phyllite, slate and amphibolites. This metamorphic complex was initially a mélange, which was subjected to regional metamorphism after the Cretaceous period [32]. 
The study area in the northeastern Mindoro Suture Zone encompasses the Mangyan Ophiolitic Complex and Lasala Formation. The Mangyan Ophiolitic Complex consists of mafic rocks such as gabbro, sheeted dike complex, and pillow lavas. However, ultramafic rocks are scarce [28,29]. The Late Eocene Lasala Formation is composed of interbedded sandstone and shale with mudstone, conglomerate, limestone, basalt flows, and dikes. The clasts of conglomerate contain mostly basalt and chert [28]. The ophiolitic fragments, mainly peridotite, of the Manyan Ophiolitic Complex were emplaced through subduction-related processes. These fragments represent the sections of the Izanagi Plate (or proto-Pacific plate) that were subducted below the southeastern margin of mainland Asia during the Middle to Late Jurassic [34,35].

The topography varies from rolling hills and moderate relief with elevation up to $300 \mathrm{~m}$ to high plateaus and sharp-crested ridges at an altitude of more than $1200 \mathrm{~m}$. The intermediate plateaus are mainly divided by incised V-shaped stream valleys. It is found that the terrain with a slope less than $30^{\circ}$ has a well-developed laterite profile above the ultramafic rocks. The laterite profile is typically thin or absent when the slope is steeper [36].

\section{Intex Ni-Co Laterite Deposit}

The Intex exploration project area lies in the Mangyan Ophiolitic Complex in the north-central part of the island, which is $40 \mathrm{~km}$ south of Calapan. A total of three laterite profiles, namely BB2515, PG1500, and BB2406, were selected for this study (Figure 1c). These profiles were chosen based on the availability of complete horizons (saprolite and limonite) and the location of the laterite profiles (topmost ridges). The Intex's concession area covers approximately $113 \mathrm{~km}^{2}$ with an elevation that ranges from $135 \mathrm{~m}$ in the northeast section to $1460 \mathrm{~m}$ near the southwest section (Figure 2).

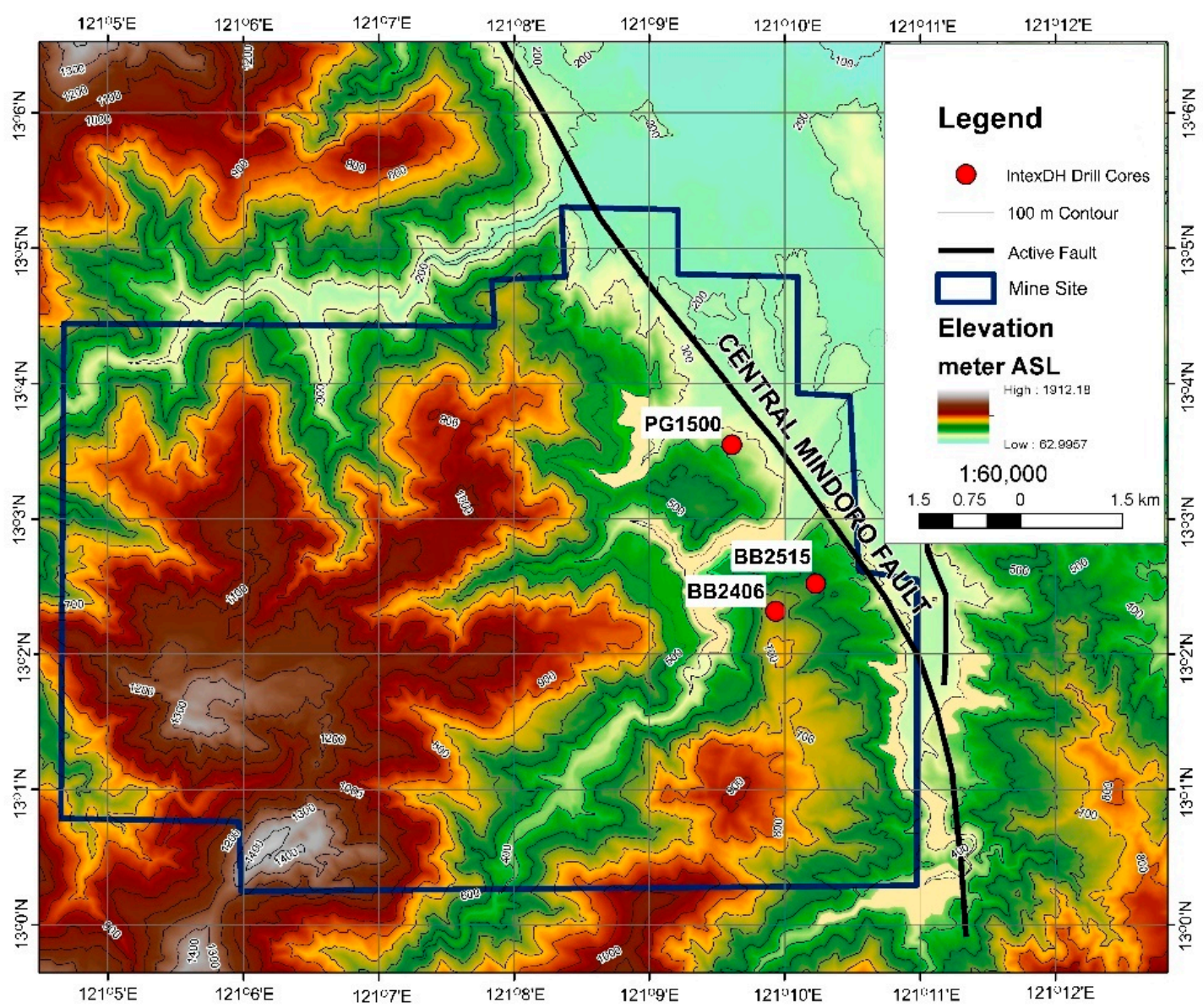

Figure 2. Relief map showing the studied drill cores within the Intex's exploration project area. 
The laterite profiles observed in the drill cores are divided from bottom to top into: (i) serpentinized ultramafic rocks, (ii) the saprolite horizon, and (iii) the limonite horizon. The bulk Fe concentration, texture and mineralogy of the rock and laterite were used to distinguish each horizon. The thickness of the laterite ranges $13-16 \mathrm{~m}$. The ultramafic rocks in the studied cores are characterized by mm-wide serpentine veins. In this study, lherzolite (BB2515 core), clinopyroxenite (PG1500 core), and harzburgite-dunite bedrock (BB2406 core) are examined (Figure 3a-c).
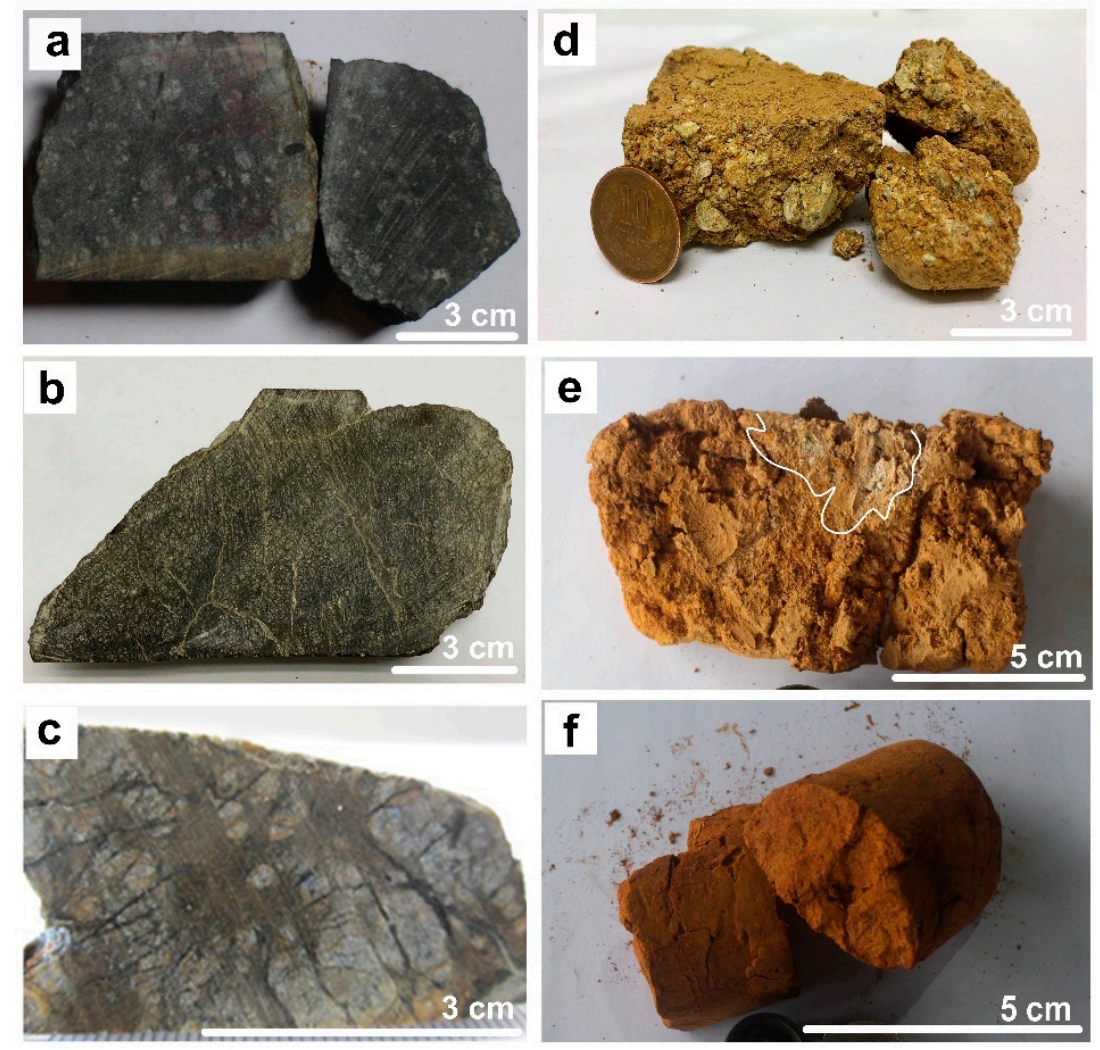

Figure 3. Photos of (a) serpentinized lherzolite (BB2515 core), (b) harzburgite-dunite (BB2406 core), and (c) clinopyroxenite (PG1500 core), (d) earthy material including pebble-sized rock remnants (e) silica-bearing limonite sample from the limonite horizon, and (f) dark orange highly weathered materials.

Overlying the serpentinized bedrock is the saprolite horizon, which is generally yellow-brown, and porous. The saprolite horizon is well developed in all studied cores with thickness ranging from 3 to $8 \mathrm{~m}$. This horizon contains a combination of earthy materials and coarse-grained to gravel-sized rock remnants (Figure 3d). Residual silica and Mn-oxyhydroxides often occur as coatings on the surface of moderately weathered rocks. The saprolite horizon derived from clinopyroxenite (PG1500) is marked by a thick layer of residual silica.

Approximately from 3 to $4.5 \mathrm{~m}$ of the limonite horizon is developed above the saprolite horizon. Irregular patches of residual silica are occasionally found on the upper section of the limonite horizon (Figure 3e). Figure $3 \mathrm{f}$ displays an example of dark-orange-colored and friable limonite.

\section{Sampling and Analytical Methods}

Samples from the bedrock, saprolite and limonite horizons were collected from the three drill cores mentioned above. These samples were air-dried at $20-30{ }^{\circ} \mathrm{C}$ for two weeks, then were quartered and powdered using mortar and pestle.

The $\mathrm{pH}$ measurements of 26 representative samples were conducted. Twenty grams of powdered sample and $20 \mathrm{~mL}$ of distilled water were transferred to a $50 \mathrm{~mL}$ container and were mixed. The mixed solution was constantly stirred for $30 \mathrm{~min}$. The $\mathrm{pH}$ meter was calibrated using $\mathrm{pH}$ 4, 7, and 10 standard 
solutions under $20-25^{\circ} \mathrm{C}$ temperature conditions. The $\mathrm{pH}$ meter was then dipped into the solution, and the sample $\mathrm{pH}$ to the nearest $0.01 \mathrm{pH}$ unit was recorded. Lastly, the electrode was rinsed with tap water followed by distilled water.

Twenty polished thin sections and polished samples were prepared. The modal proportions of olivine, orthopyroxene, clinopyroxene, talc, and serpentine in the bedrock were determined by the point-counting method under an optical microscope. A total of 2500 points were covered for each polished thin section. The saprolite and limonite samples were impregnated with petropoxy resin prior to sectioning and polishing.

The bulk mineralogy of the samples was analyzed using X-ray Powder Diffraction (XRPD). The MultiFlex XRPD (Rigaku, Tokyo, Japan) with $\mathrm{Cu} K \alpha$ radiation source was operated at $30 \mathrm{kV}$, $10 \mathrm{~mA}$, step size of $0.02^{\circ}$ and a scan step of $20^{\circ}$ per minute. The XRPD machine is available at the Graduate School of International Resource Sciences, Akita University, Japan. Mineral identification was accomplished using the COD reference database of MATCH! software-based on "figure-of-merit" values and visual inspection relative to the experimental diffraction pattern.

The polymorphs of serpentine were distinguished using an inVia Raman microscope (Renishaw, Gloucestershire, United Kingdom) of Akita University. This instrument is equipped with a $100 \mathrm{~mW}$ $532 \mathrm{~nm}$ frequency-doubled Nd: YAG laser and a CCD detector. A total of 1800 lines/mm grating was used to disperse the signal onto the CCD detector. Before the analysis of polished thin sections, the analyzer was calibrated using the Si-Au standard. A range of from ten to fifty percent laser power was used, and the minerals were observed under a $50 \times$ objective lens. Both the spectra from low wavenumbers $\left(100-500 \mathrm{~cm}^{-1}\right)$ and high wavenumbers $\left(3600-4000 \mathrm{~cm}^{-1}\right)$ were collected for mineral identification. The background fluorescence and noise were removed using the WiRE ${ }^{\mathrm{TM}}$ software (Renishaw, Gloucestershire, United Kingdom). The Raman signatures of the serpentine polymorphs of this study were compared to the previous results $[20,37,38]$.

The chemical composition of the silicate and oxide minerals was acquired by the Field Emission Electron Probe Microanalyzer (JEOL JXA-8530F, Tokyo, Japan) of the Geological Survey of Japan (GSJ), National Institute of Advanced Industrial Science and Technology (AIST) in Tsukuba, Japan. The operating conditions were $20 \mathrm{kV}$ voltage, $20 \mathrm{nA}$ probe current, and a beam diameter of $5 \mu \mathrm{m}$. Various JEOL reference standards were utilized to calibrate the instrument including $\mathrm{MgO}(\mathrm{Mg}$, $\mathrm{TAPH}$, $\mathrm{K} \alpha$ ), $\mathrm{SiO}_{2}\left(\mathrm{Si}\right.$, TAP, $\mathrm{K} \alpha$ ), $\mathrm{Al}_{2} \mathrm{O}_{3}\left(\mathrm{Al}, \mathrm{TAPH}, \mathrm{K} \alpha\right.$ ), $\mathrm{Fe}_{2} \mathrm{O}_{3}(\mathrm{Fe}, \mathrm{LIFH}, \mathrm{K} \alpha), \mathrm{MnO}\left(\mathrm{Mn}, \mathrm{LIFH}, \mathrm{K} \alpha\right.$ ), $\mathrm{CaSiO}_{3}$ $(\mathrm{Ca}, \mathrm{PETH}, \mathrm{K} \alpha), \mathrm{NiO}(\mathrm{Ni}, \mathrm{LIFH}, \mathrm{K} \alpha), \mathrm{CoO}(\mathrm{Co}, \mathrm{LIFH}, \mathrm{K} \alpha)$ and $\mathrm{Cr}_{2} \mathrm{O}_{3}(\mathrm{Cr}, \mathrm{LIFH}, \mathrm{K} \alpha)$. The raw counts were corrected using a ZAF (atomic number, absorption, fluorescence) procedure.

The whole-rock composition of representative samples was obtained by X-ray Fluorescence (XRF) spectrometer (Rigaku ZSX Primus III+, Tokyo, Japan). Forty powdered samples were oven-dried at $105{ }^{\circ} \mathrm{C}$ in an oven for over $30 \mathrm{~min}$. The mixture of $0.5 \mathrm{~g}$ sample and di-lithium tetraborate was fused at $1250^{\circ} \mathrm{C}$ in a Pt crucible using a high-frequency fusion instrument (HERZOG HAG-M-HF, Germany). Then this mixture was cooled on a Pt disk, and the fused glass beads were analyzed using the XRF spectrometer. A $50 \mathrm{kV}$ voltage and a current of $50 \mathrm{~mA}$ was used. Two calibration curves were prepared using a different set of OREAS reference standards for $\mathrm{SiO}_{2}, \mathrm{Al}_{2} \mathrm{O}_{3}, \mathrm{P}_{2} \mathrm{O}_{5}, \mathrm{TiO}_{2}, \mathrm{Cr}_{2} \mathrm{O}_{3}, \mathrm{MnO}$, $\mathrm{Fe}_{2} \mathrm{O}_{3}, \mathrm{Co}_{2} \mathrm{O}_{3}$, and $\mathrm{NiO}$, whereas GSJ standards for $\mathrm{Na}_{2} \mathrm{O}, \mathrm{MgO}, \mathrm{K}_{2} \mathrm{O}$, and $\mathrm{CaO}$. Five international standards, including JP-A (peridotite), JB-1b (basalt), JG-3 (granodiorite), OREAS 401 (Fe ore), OREAS 180 and OREAS 184 (Ni laterite ore) were used to evaluate the accuracy of the analytical results. The loss-on-ignition (LOI) of each representative sample was obtained. Both XRF and LOI were done at GSJ, AIST in Tsukuba.

\section{Results}

\subsection{XRPD Analysis}

Figures 4 and 5 show the XRPD pattern of the bedrock and laterite samples, and corresponding $\mathrm{d}$-spacing values of each mineral. The interplanar spacing between the atoms in the crystal (d-spacing) 
was calculated using Bragg's equation $(n \lambda=2 d \sin \theta)$, where $\mathrm{n}$ is a positive integer (first order Bragg diffraction peak), and lambda $\lambda$ is the wavelength of the incident wave. Serpentine, olivine, pyroxene are the dominant minerals in the bedrock with a trace amount of chromite (Figure 4). The strong reflection at $7.25 \AA$ and weaker reflections at 4.60 and $3.60 \AA$ are characteristics of serpentine. In the saprolite horizon, serpentine is the major mineral, whereas chromite, goethite, talc, quartz, actinolite, relict olivine, and pyroxene occur as accessory constituents (Figure 4). The minor peaks at 3.12 and $8.40 \AA$ A belong to actinolite (Figure 5a). The limonite horizon consists mainly of goethite. Hematite, talc, chromite, magnetite, asbolane, and quartz occur in minor to trace amounts. XRPD analysis of the limonite samples shows the occurrence of talc of which reflections are at $9.36 \AA\left(\mathrm{d}_{001}\right), 4.67 \AA\left(\mathrm{d}_{002}\right)$ and $3.12 \AA\left(\mathrm{d}_{003}\right)$ (Figure 5a). The $9.44 \AA$ and $4.74 \AA$ A peaks belong to asbolane (Figure $5 \mathrm{~b}$ ).

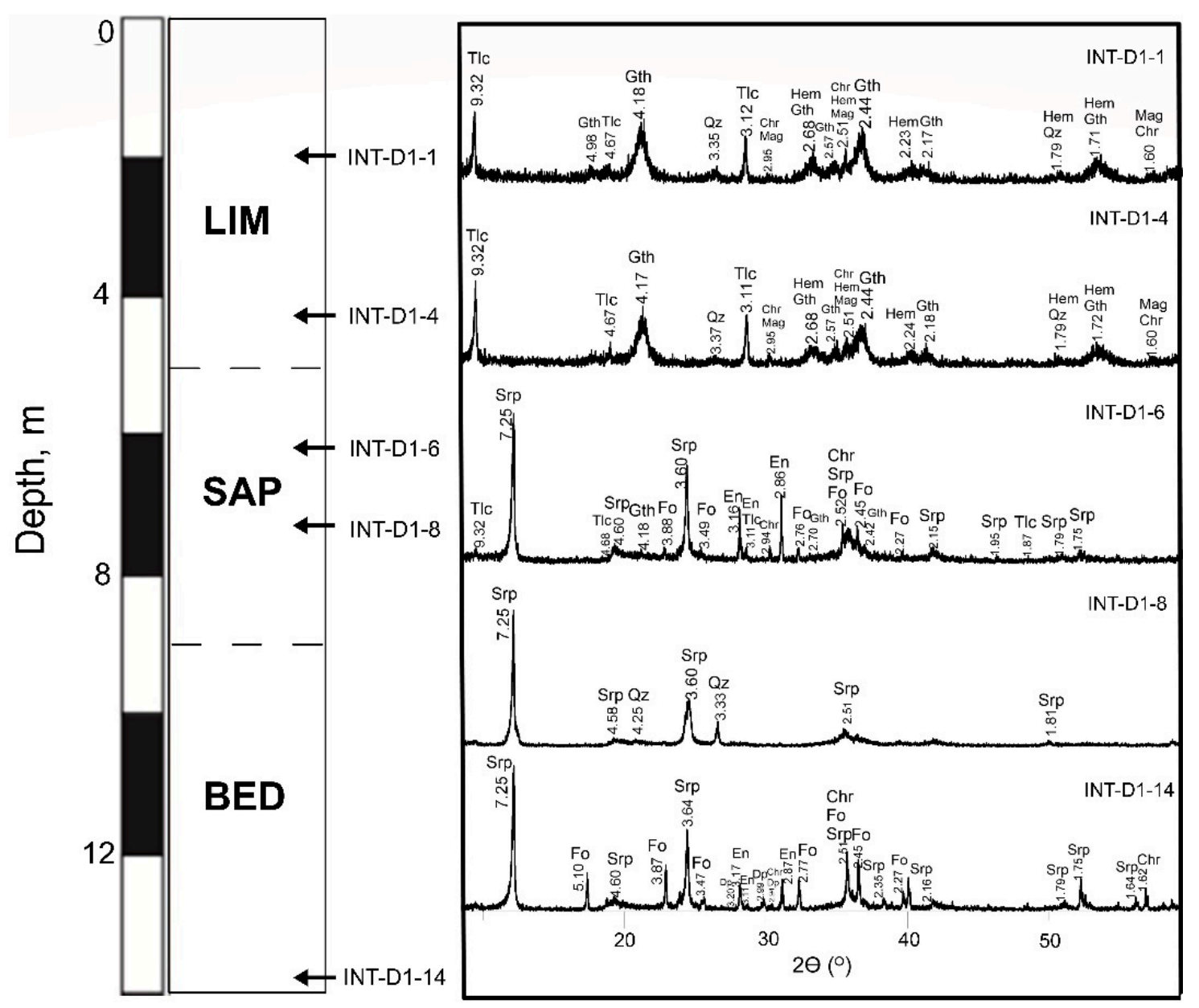

Figure 4. Stacked XRPD patterns of bedrock, saprolite, and limonite representative samples from BB2515 drill core. Fo-forsterite, En-enstatite, Srp—serpentine, Tlc—talc, Qz-quartz, Chr-chromite, Mag—magnetite, Gth—goethite, Hem—hematite. 


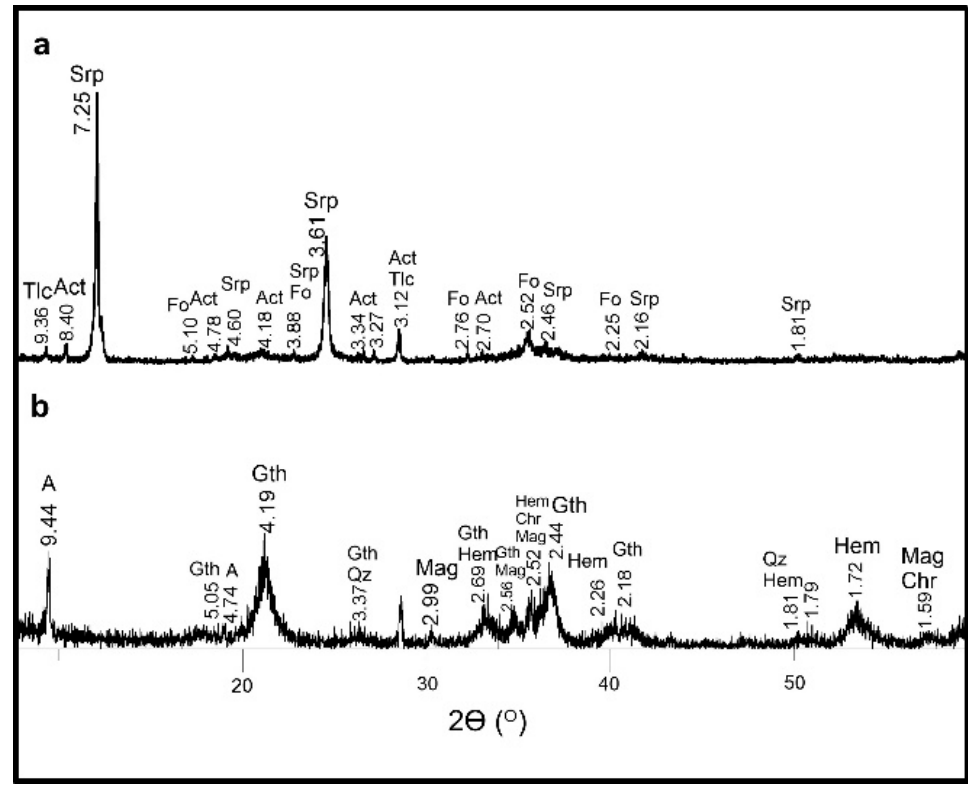

Figure 5. XRPD patterns of samples showing the (a) occurrence of serpentine, actinolite, talc and relict olivine, and (b) presence of asbolane with goethite, hematite, magnetite, chromite, and quartz. Srp-serpentine, Act-actinolite, Fo-forsterite, Tlc-talc, A-asbolane, Gth-goethite, Mag-magnetite, Hem—hematite, Chr—chromite, Qz-quartz.

\subsection{Mineral Descriptions}

Based on the modal proportions of primary olivine ( $>50-72 \%)$, orthopyroxene (20-36\%), and clinopyroxene (8-13\%), two bedrock samples from BB2515 core are identified as lherzolite. However, the BB2406 core has two different bedrock types, namely harzburgite and dunite. Dunite contains $99 \%$ olivine and $1 \%$ orthopyroxene, whereas harzburgite consists of $85 \%$ olivine, $11 \%$ orthopyroxene, and $4 \%$ clinopyroxene. Although there was no fresh bedrock sample from PG1500 drill core, previous work [39] reported that the bedrock type from this core is clinopyroxenite.

A network of serpentine cuts the primary minerals in all the studied bedrock. The serpentine veins contain discontinuous strings of magnetite (Figure 6a). The peridotite bedrock from BB2515 and BB2406 cores are characterized by three types of serpentine veins including mesh-textured type I and type II veins and the interlocking-textured type III veins. Fine- to coarse-grained magnetite outlines the core of type II veins, whereas the rim is free from magnetite (Figure 6a). The type III veins are wider, generally hundreds of micrometers to a millimeter in width. Talc has a characteristically high birefringence under cross-polarized light. Figure $6 \mathrm{~b}$ shows that fine-grained talc replaces type III serpentines. Microscopic observations show that talc is more dominant in lherzolite in contrast to harzburgite-dunite bedrock. Chromite occurs in various shapes and sizes but is typically subhedral in form (Figure 6b).

Three types of serpentine veins are identified in the saprock derived from lherzolite bedrock (Figure 6c). The textural features of these veins are analogous to the previous veins identified in the bedrock. Type I veins contain disseminated magnetite and pseudomorph the former primary olivine and pyroxene. Type II veins have distinct magnetite rich core and cut through type I veins. Type III veins are characterized by interlocking texture (Figure 6c). Similarly, the saprock derived from harzburgite-dunite bedrock shows type I to type III serpentine veins, and these are subsequently cut by yellow-orange, discontinuous type IV veins, which are often associated with magnetite (Figure 6d). The saprock developed above clinopyroxenite is marked by type I and type $\mathrm{V}$ veins. Type I veins are characterized by interpenetrating texture (Figure 6e) and are cut by type $\mathrm{V}$ serpentine veins (Figure 6f). Hematite is widely distributed within type $\mathrm{V}$ veins (Figure 6f). 


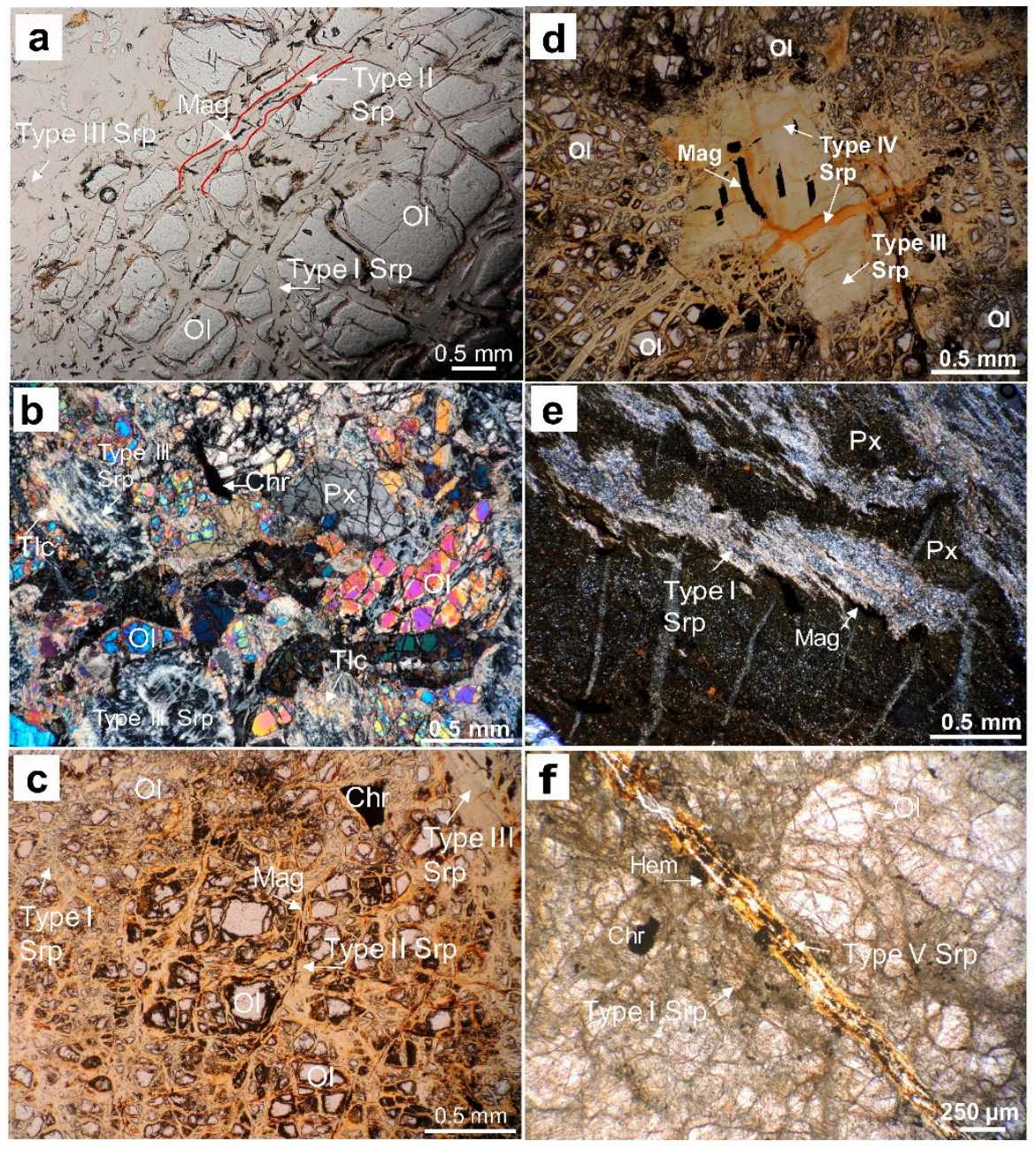

Figure 6. Photomicrographs of $(\mathbf{a}, \mathbf{b})$ type I, II and III serpentine veins cutting primary olivine, pyroxene, chromite, and Fe-oxide in lherzolite (BB2515 core); serpentine veins in the saprock developed above (c) lherzolite (BB2515 core), (d) harzburgite-dunite (BB2406 core), and (e,f) clinopyroxenite (PG1500 core). $\mathrm{Ol}$-olivine, Px—pyroxene, Srp—serpentine, Tlc—talc, Chr—chromite, Gth—goethite.

\subsection{Raman Characterization of Serpentine in the Bedrock and Saprolite}

Figure 7 displays the Raman peaks of different types of serpentine formed in the studied bedrock. The Raman peaks of type I serpentines exhibit strong peaks at 228, 381, and $688 \mathrm{~cm}^{-1}$. Type II and type III serpentines show a comparable set of bands as type I serpentines. The high-frequency domains display sharp peaks at $3676,3679,3684$, and $3685 \mathrm{~cm}^{-1}$. The Raman signatures of the three types of serpentine in the lherzolite bedrock belong to lizardite.

The saprolite horizon developed above lherzolite and harzburgite-dunite is characterized by the frequent presence of type I, type II-rim, type II-core, and type III serpentines with the addition of type IV serpentines (Figure 8). The main peaks of type I serpentines are positioned at 228, 383 , and $688 \mathrm{~cm}^{-1}$. The extra reflections at 827 and $857 \mathrm{~cm}^{-1}$ correspond to the relict phase of olivine. The high-frequency domains reveal sharp peaks at $3679,3682,3683$ and $3684 \mathrm{~cm}^{-1}$. Both the low-frequency and high-frequency domains of type I to type IV serpentines in the saprock derived from harzburgite-dunite match the signature of lizardite. However, the Raman peaks of type I in the saprock derived from clinopyroxenite belong to antigorite. Here, the low-frequency domains show intense peaks at 230,375, and $684 \mathrm{~cm}^{-1}$, whereas, in the high-frequency domain, the strong peak is at $3667 \mathrm{~cm}^{-1}$ (Figure 9). Conversely, the Raman bands of type V serpentines in the saprock developed above clinopyroxenite are identified as chrysotile (Figure 9). The Raman signatures of 
lizardite (3679-3684 cm-1$)$ are differentiated from antigorite $\left(3667 \mathrm{~cm}^{-1}\right)$ and chrysotile $\left(3694 \mathrm{~cm}^{-1}\right)$ based on the strong peaks in the high-frequency domain.
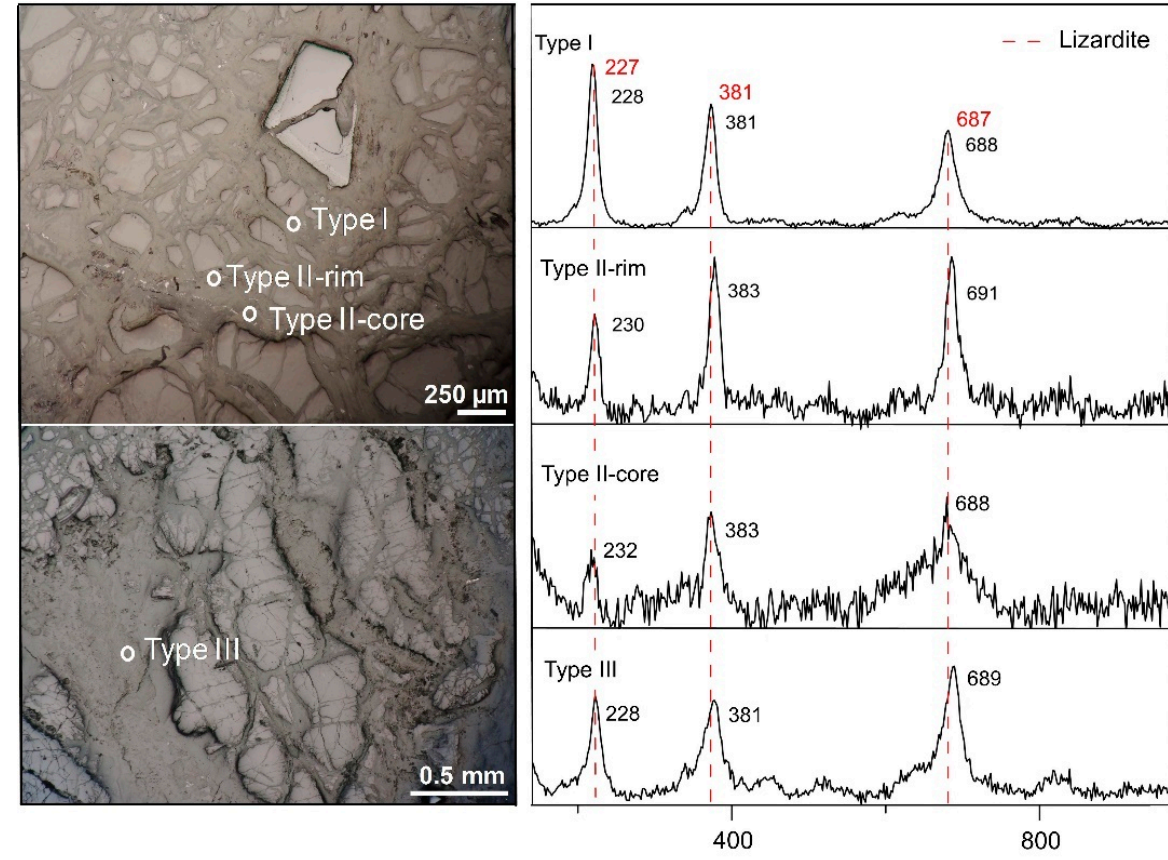

Raman shift $\left(\mathrm{cm}^{-1}\right)$
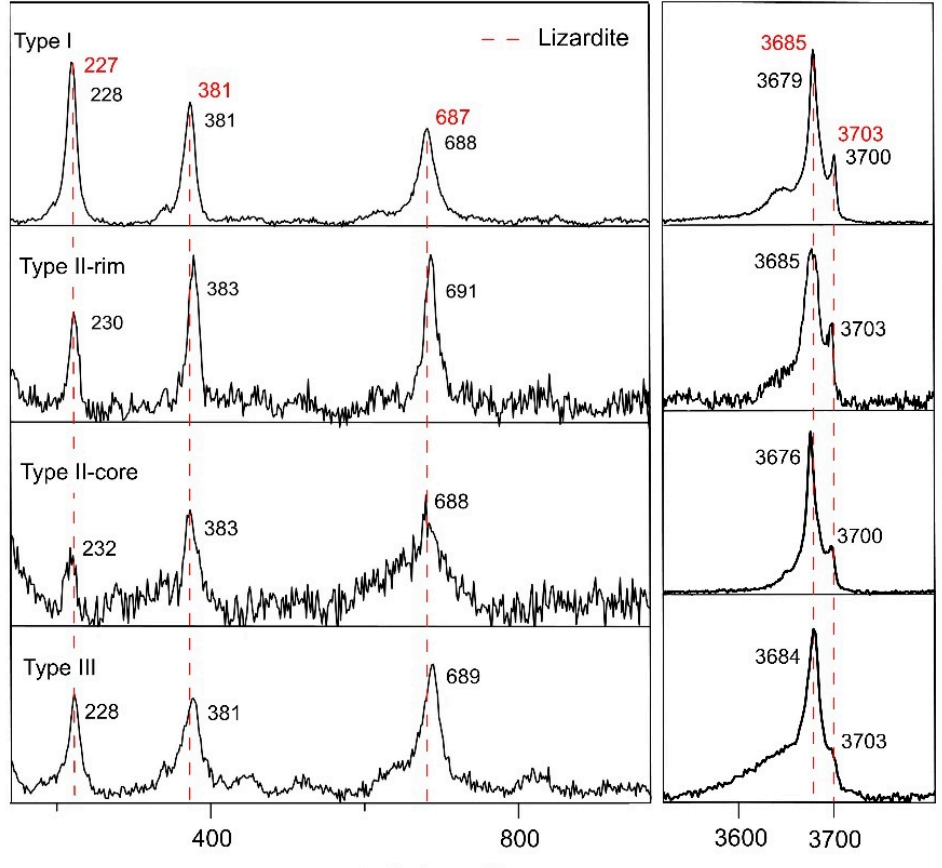

Figure 7. Raman signatures of type I, type II and type III vein serpentines identified in the lherzolite bedrock. Red dashed lines indicate the Raman bands from previous work [21].
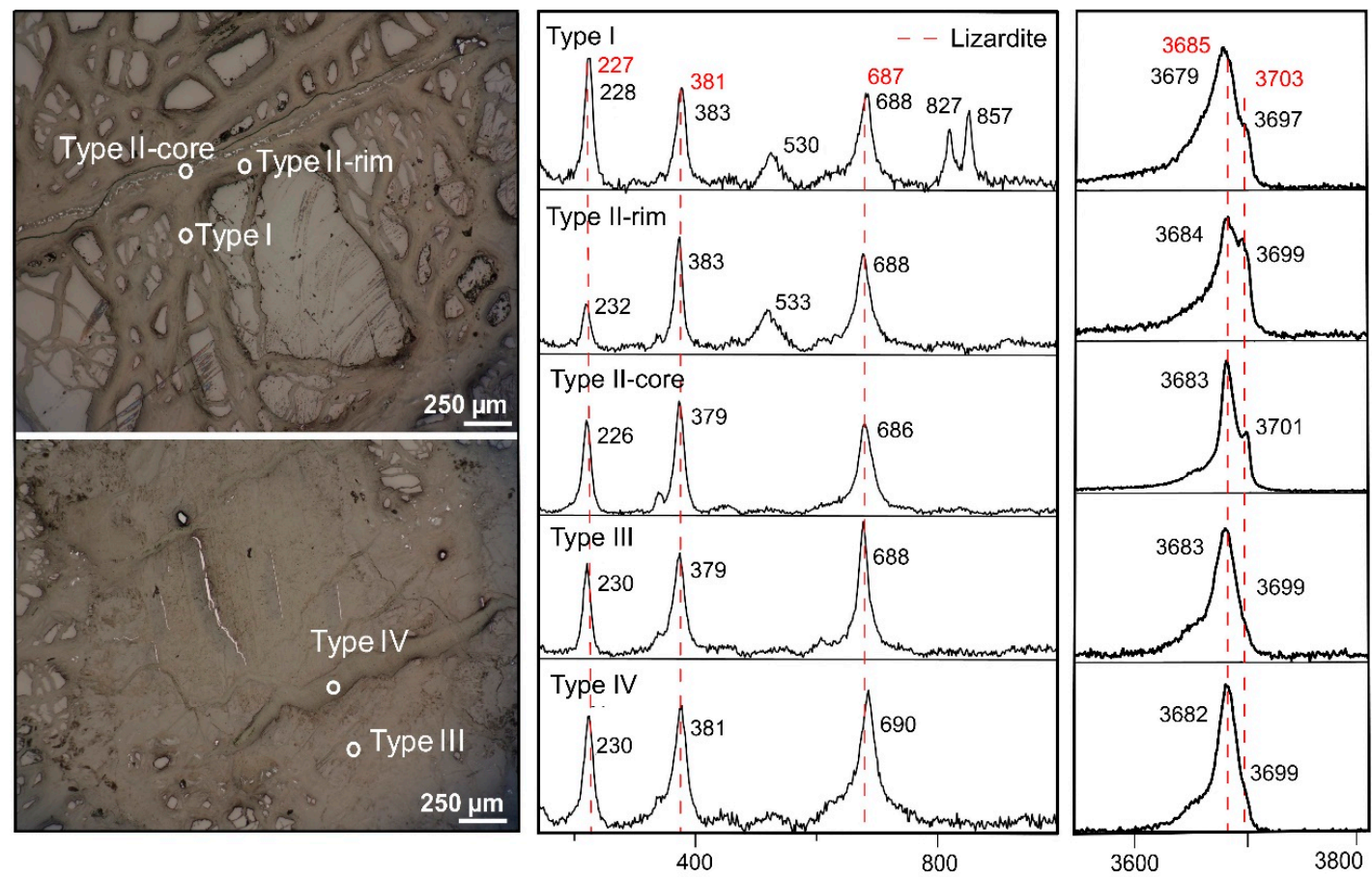

Raman shift $\left(\mathrm{cm}^{-1}\right)$

Figure 8. Raman signatures of type I, type II, type III and type IV vein serpentines identified in the saprock derived from harzburgite-dunite (BB2406 core). Red dashed lines indicate the Raman bands from previous work [21]. 


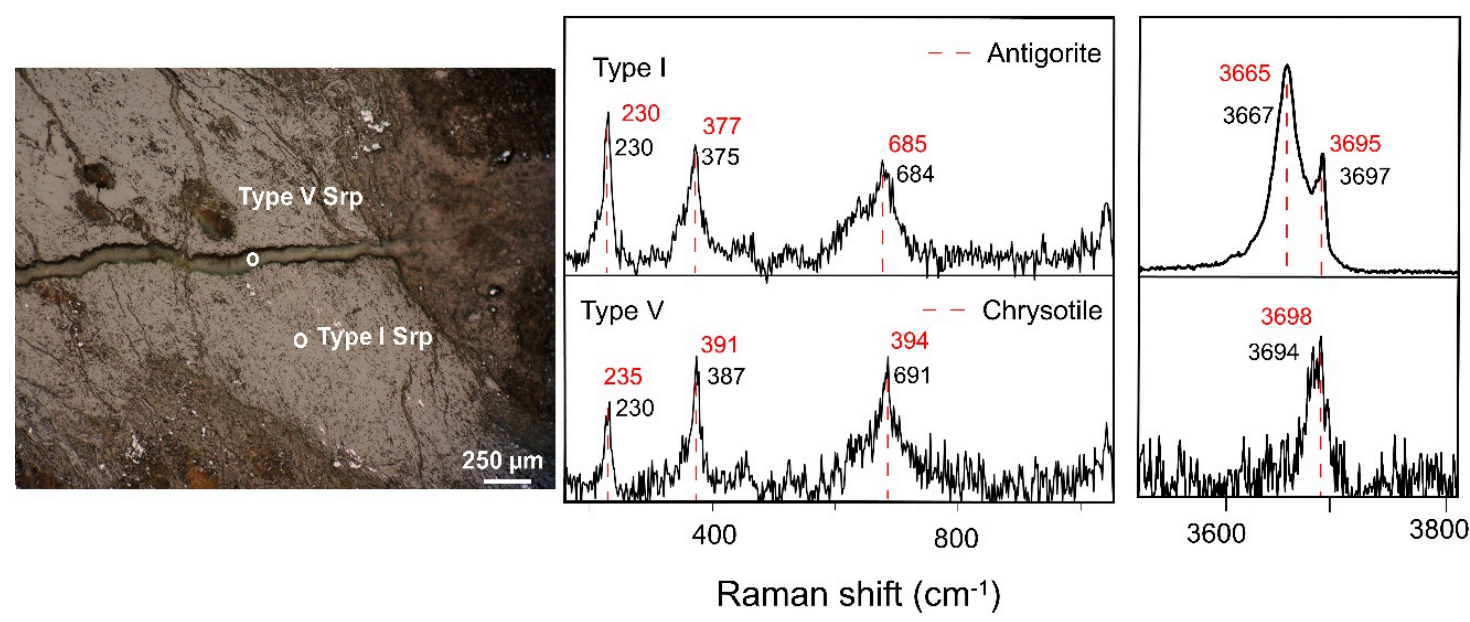

Figure 9. Raman signatures of type I and type V vein serpentines identified in the saprock developed above clinopyroxenite bedrock (PG1500 core). Red dashed lines indicate the Raman bands from previous work [21,39].

\subsection{Mineral Chemistry}

The bedrock samples show that the highest $\mathrm{NiO}$ concentration is measured in primary olivine (average $0.37 \mathrm{wt} \% ; 0.01 \mathrm{apfu} \mathrm{Ni)}$ with a considerable amount of $\mathrm{FeO}$ (average $8.42 \mathrm{wt} \%$ ) (Figure 10a). Orthopyroxene and clinopyroxene are marked by relatively high $\mathrm{FeO}$ concentrations (average $5.56 \mathrm{wt} \%$, average $1.78 \mathrm{wt} \%$ ) (Table 1). Talc commonly occurs as fine aggregates in the bedrock and it contains a substantial amount of $\mathrm{FeO}$ (average $1.75 \mathrm{wt} \%$ ) and $\mathrm{Al}_{2} \mathrm{O}_{3}$ (average $1.24 \mathrm{wt} \%$ ), but with low $\mathrm{NiO}$ concentration (average $0.07 \mathrm{wt} \%$ ). The average structural formula of talc is $\mathrm{Mg}_{2.93} \mathrm{Si}_{3.89} \mathrm{O}_{10}(\mathrm{OH})_{2}$.

Table 1. Average chemical compositions (wt \%) and structural formula (apfu) of olivine, orthopyroxene, clinopyroxene, and talc in the peridotite bedrock.

\begin{tabular}{|c|c|c|c|c|c|c|c|c|}
\hline \multirow{3}{*}{$\begin{array}{c}\text { Mineral } \\
n\end{array}$} & \multicolumn{2}{|c|}{ Olivine } & \multicolumn{2}{|c|}{ Orthopyroxene } & \multicolumn{2}{|c|}{ Clinopyroxene } & \multicolumn{2}{|c|}{ Talc } \\
\hline & & $\Sigma$ & & $\sigma$ & & $\sigma$ & & $\sigma$ \\
\hline & 18 & & 12 & & 6 & & 4 & \\
\hline $\mathrm{SiO}_{2}$ & 39.99 & 0.44 & 55.75 & 0.48 & 53.22 & 1.37 & 58.28 & 2.17 \\
\hline $\mathrm{Al}_{2} \mathrm{O}_{3}$ & 0.01 & 0.02 & 1.69 & 0.22 & 0.97 & 0.41 & 1.24 & 0.78 \\
\hline $\mathrm{FeO}$ & 8.42 & 0.37 & 5.56 & 0.09 & 1.78 & 0.15 & 1.75 & 0.33 \\
\hline $\mathrm{MgO}$ & 50.70 & 2.18 & 35.39 & 0.38 & 20.03 & 2.89 & 28.87 & 0.60 \\
\hline $\mathrm{NiO}$ & 0.37 & 0.03 & 0.07 & 0.01 & 0.04 & 0.02 & 0.07 & 0.01 \\
\hline $\mathrm{CoO}$ & 0.02 & 0.01 & 0.01 & 0.01 & 0.00 & 0.00 & 0.01 & 0.02 \\
\hline $\mathrm{CaO}$ & 0.01 & 0.03 & 0.54 & 0.23 & 24.41 & 1.37 & 0.02 & 0.01 \\
\hline $\mathrm{Cr}_{2} \mathrm{O}_{3}$ & 0.00 & 0.00 & 0.48 & 0.09 & 0.30 & 0.21 & 0.30 & 0.16 \\
\hline $\mathrm{MnO}$ & 0.12 & 0.01 & 0.13 & 0.01 & 0.07 & 0.02 & 0.02 & 0.01 \\
\hline Total & 99.66 & 2.73 & 99.66 & 0.39 & 100.85 & 0.31 & 90.56 & 2.09 \\
\hline $\mathrm{Si}$ & 0.981 & 0.021 & 1.931 & 0.010 & 1.922 & 0.048 & 3.915 & 0.080 \\
\hline $\mathrm{Al}$ & 0.000 & 0.001 & 0.069 & 0.009 & 0.041 & 0.017 & 0.098 & 0.062 \\
\hline $\mathrm{Fe}$ & 0.173 & 0.004 & 0.161 & 0.003 & 0.054 & 0.005 & 0.099 & 0.019 \\
\hline$\sum$ Tetra. & 1.154 & 0.018 & 2.161 & 0.005 & 2.017 & 0.054 & 4.113 & 0.039 \\
\hline $\mathrm{Mg}$ & 1.854 & 0.040 & 1.827 & 0.017 & 1.079 & 0.157 & 2.893 & 0.077 \\
\hline $\mathrm{Ni}$ & 0.007 & 0.001 & 0.002 & 0.000 & 0.001 & 0.000 & 0.004 & 0.001 \\
\hline Co & 0.000 & 0.000 & 0.000 & 0.000 & 0.000 & 0.000 & 0.001 & 0.001 \\
\hline $\mathrm{Cr}$ & 0.000 & 0.000 & 0.013 & 0.002 & 0.009 & 0.006 & 0.016 & 0.008 \\
\hline $\mathrm{Ca}$ & 0.000 & 0.001 & 0.020 & 0.009 & 0.945 & 0.052 & 0.001 & 0.001 \\
\hline $\mathrm{Mn}$ & 0.003 & 0.000 & 0.004 & 0.000 & 0.002 & 0.001 & 0.001 & 0.001 \\
\hline$\sum$ Oct. & 1.864 & 0.039 & 1.867 & 0.011 & 2.035 & 0.105 & 2.915 & 0.082 \\
\hline Tetra./Oct. & 0.620 & 0.025 & 1.158 & 0.009 & 0.994 & 0.072 & 1.412 & 0.052 \\
\hline $\mathrm{Ni} / \mathrm{Mg}$ & 0.004 & 0.000 & 0.001 & 0.000 & 0.001 & 0.000 & 0.001 & 0.000 \\
\hline
\end{tabular}

$n$ total number of points acquired in polished thin section; $\sigma$ standard deviation of the analyzed points apfu atoms per formula unit. 

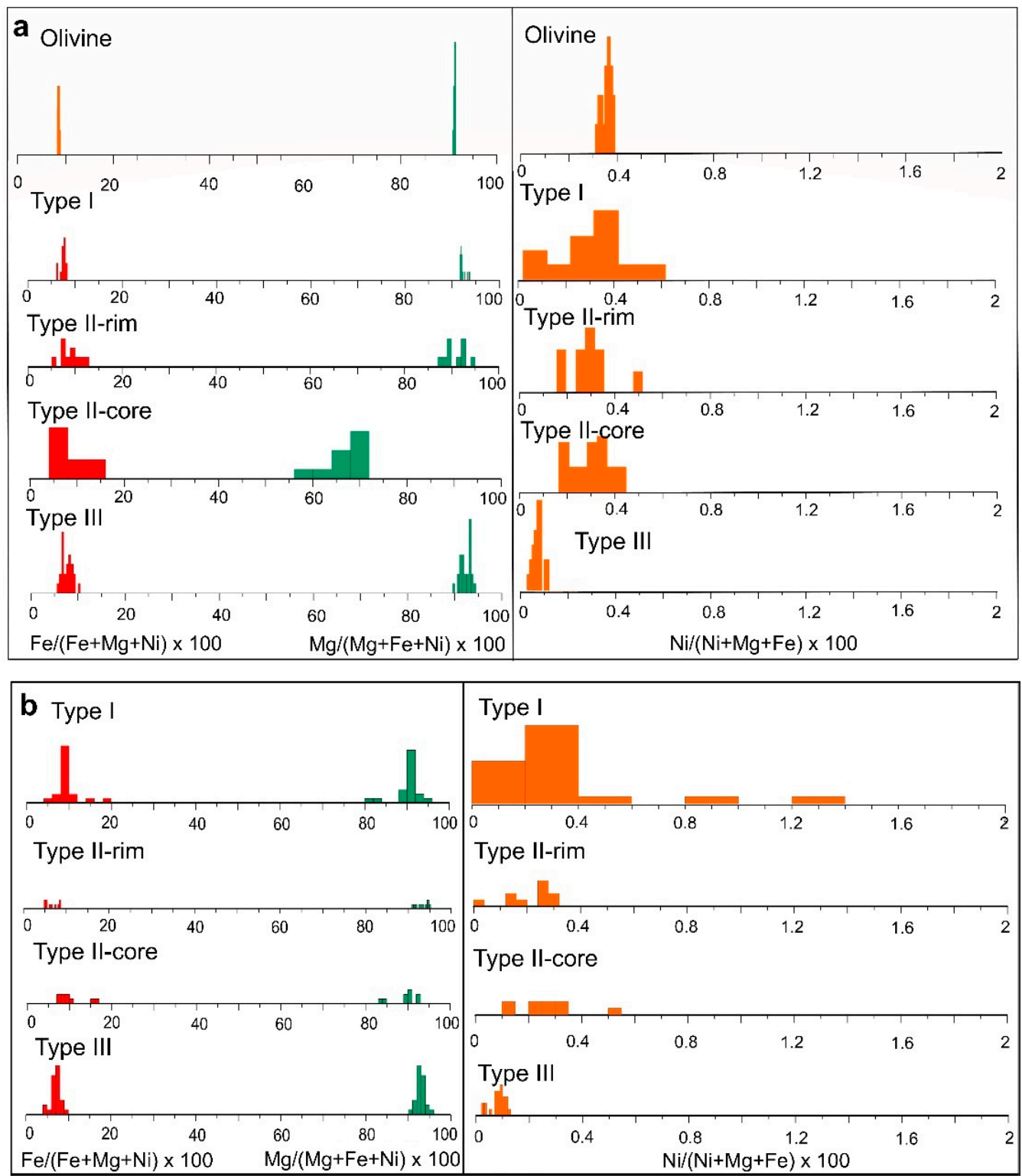

Figure 10. Histogram of $\mathrm{Mg}$ (green), $\mathrm{Fe}$ (red) and $\mathrm{Ni}$ (orange) mol ratio in olivine and the different types of serpentine identified in the (a) lherzolite and (b) harzburgite-dunite bedrock.

The FeO content of type I, type II-rim and type II-core serpentines (average $6.30 \mathrm{wt} \%$, average $5.85 \mathrm{wt} \%$, average $8.17 \mathrm{wt} \%$ ) is higher compared with type III serpentines (average $5.13 \mathrm{wt} \%$ ) in the lherzolite and harzburgite-dunite bedrock (Table 2). The MgO concentration of type I and type II-rim serpentines (average $37.56 \mathrm{wt} \%$, average $38.37 \mathrm{wt} \%$ ) is higher than type II-core and type III serpentines (average $36.48 \mathrm{wt} \%$, average $36.26 \mathrm{wt} \%$ ) in either bedrock. The sudden decrease in the $\mathrm{Mg} /(\mathrm{Mg}+\mathrm{Fe}$ $+\mathrm{Ni}$ ) ratio from type II-rim to type II-core and type III serpentines is clearly shown in Figure 10a. The $\mathrm{NiO}$ contents of type I and type II serpentines in the bedrock are similar (average $0.22 \mathrm{wt} \%, 0.009$ apfu), but type III serpentines are distinctively lower (0.06 wt $\%, 0.002 \mathrm{apfu}$ ) (Table 2). The Ni/(Ni $+\mathrm{Mg}$ $+\mathrm{Fe}$ ) ratio from type I to type III serpentines decreases in the bedrock (Figure 10a,b). 
Table 2. Average chemical compositions (wt \%) and structural formula (apfu) of the different vein serpentines in the bedrock.

\begin{tabular}{|c|c|c|c|c|c|c|c|c|c|c|c|c|c|c|c|c|}
\hline \multirow{2}{*}{$\begin{array}{l}\text { Drill } \\
\text { Core }\end{array}$} & \multicolumn{2}{|l|}{ BB2515 } & \multicolumn{2}{|l|}{ BB2406 } & \multirow{2}{*}{\begin{tabular}{|c|} 
BB2515 \\
Type II-rim
\end{tabular}} & \multicolumn{3}{|c|}{ BB2406 } & \multicolumn{2}{|l|}{ BB2515 } & \multicolumn{2}{|l|}{ BB2406 } & \multicolumn{2}{|l|}{ BB2515 } & \multicolumn{2}{|l|}{ BB2406 } \\
\hline & Type I & $\sigma$ & Type I & $\sigma$ & & $\sigma$ & Type II-rim & $\sigma$ & Type II-core & $\sigma$ & Type II-core & $\sigma$ & Type III & $\sigma$ & Type III & $\sigma$ \\
\hline$n$ & 14 & & 20 & & 10 & & 10 & & 11 & & 9 & & 26 & & 25 & \\
\hline $\mathrm{SiO}_{2}$ & 38.65 & 1.58 & 37.27 & 2.60 & 37.14 & 2.98 & 39.43 & 1.33 & 35.51 & 4.95 & 36.67 & 1.85 & 39.55 & 0.63 & 40.40 & 1.47 \\
\hline $\mathrm{Al}_{2} \mathrm{O}_{3}$ & 0.32 & 0.37 & 0.11 & 0.10 & 0.05 & 0.05 & 0.03 & 0.02 & 0.04 & 0.03 & 0.02 & 0.02 & 1.93 & 0.62 & 2.34 & 1.66 \\
\hline $\mathrm{FeO}$ & 5.43 & 0.47 & 7.16 & 2.28 & 6.91 & 2.01 & 4.79 & 1.05 & 8.74 & 7.28 & 7.59 & 2.41 & 5.35 & 0.79 & 4.88 & 0.90 \\
\hline $\mathrm{MgO}$ & 37.40 & 1.94 & 37.71 & 1.99 & 38.95 & 1.94 & 37.79 & 0.75 & 36.45 & 5.10 & 36.50 & 1.71 & 36.59 & 0.86 & 35.92 & 0.99 \\
\hline $\mathrm{NiO}$ & 0.22 & 0.10 & 0.27 & 0.25 & 0.24 & 0.06 & 0.16 & 0.07 & 0.23 & 0.06 & 0.20 & 0.09 & 0.05 & 0.01 & 0.06 & 0.02 \\
\hline $\mathrm{CoO}$ & 0.01 & 0.01 & 0.02 & 0.02 & 0.01 & 0.01 & 0.01 & 0.01 & 0.02 & 0.01 & 0.04 & 0.04 & 0.01 & 0.01 & 0.01 & 0.01 \\
\hline $\mathrm{CaO}$ & 0.22 & 0.19 & 0.10 & 0.05 & 0.14 & 0.07 & 0.04 & 0.02 & 0.12 & 0.04 & 0.05 & 0.02 & 0.11 & 0.13 & 0.04 & 0.03 \\
\hline $\mathrm{Cr}_{2} \mathrm{O}_{3}$ & 0.13 & 0.24 & 0.01 & 0.01 & 0.00 & 0.00 & 0.01 & 0.01 & 0.01 & 0.01 & 0.01 & 0.01 & 0.47 & 0.13 & 0.73 & 0.65 \\
\hline $\mathrm{MnO}$ & 0.09 & 0.04 & 0.11 & 0.04 & 0.10 & 0.03 & 0.09 & 0.04 & 0.08 & 0.02 & 0.13 & 0.11 & 0.08 & 0.03 & 0.09 & 0.03 \\
\hline Total & 82.48 & 1.34 & 82.76 & 1.24 & 83.53 & 1.09 & 82.36 & 1.01 & 81.19 & 2.61 & 81.20 & 1.78 & 84.17 & 1.02 & 84.51 & 1.16 \\
\hline $\mathrm{Si}$ & 1.949 & 0.062 & 1.898 & 0.098 & 1.874 & 0.119 & 1.978 & 0.036 & 1.858 & 0.144 & 1.908 & 0.073 & 1.945 & 0.021 & 1.969 & 0.070 \\
\hline $\mathrm{Al}$ & 0.019 & 0.022 & 0.006 & 0.006 & 0.003 & 0.003 & 0.002 & 0.001 & 0.002 & 0.002 & 0.001 & 0.001 & 0.112 & 0.036 & 0.135 & 0.095 \\
\hline $\mathrm{Fe}$ & 0.229 & 0.021 & 0.307 & 0.106 & 0.293 & 0.090 & 0.202 & 0.047 & 0.416 & 0.436 & 0.331 & 0.105 & 0.220 & 0.034 & 0.199 & 0.037 \\
\hline$\sum$ Tetra. & 2.197 & 0.069 & 2.211 & 0.092 & 2.170 & 0.067 & 2.181 & 0.028 & 2.276 & 0.311 & 2.240 & 0.106 & 2.277 & 0.037 & 2.303 & 0.036 \\
\hline $\mathrm{Mg}$ & 2.812 & 0.148 & 2.866 & 0.158 & 2.934 & 0.171 & 2.826 & 0.043 & 2.844 & 0.213 & 2.833 & 0.148 & 2.683 & 0.045 & 2.610 & 0.050 \\
\hline $\mathrm{Ni}$ & 0.009 & 0.004 & 0.011 & 0.010 & 0.010 & 0.003 & 0.007 & 0.003 & 0.010 & 0.002 & 0.008 & 0.004 & 0.002 & 0.001 & 0.002 & 0.001 \\
\hline Co & 0.001 & 0.000 & 0.001 & 0.001 & 0.000 & 0.000 & 0.000 & 0.000 & 0.001 & 0.001 & 0.002 & 0.002 & 0.001 & 0.000 & 0.000 & 0.000 \\
\hline $\mathrm{Cr}$ & 0.005 & 0.009 & 0.000 & 0.000 & 0.000 & 0.000 & 0.000 & 0.000 & 0.000 & 0.000 & 0.000 & 0.000 & 0.018 & 0.005 & 0.028 & 0.025 \\
\hline $\mathrm{Ca}$ & 0.012 & 0.011 & 0.006 & 0.003 & 0.007 & 0.004 & 0.002 & 0.001 & 0.007 & 0.002 & 0.003 & 0.001 & 0.006 & 0.007 & 0.002 & 0.001 \\
\hline $\mathrm{Mn}$ & 0.004 & 0.002 & 0.005 & 0.002 & 0.004 & 0.001 & 0.004 & 0.002 & 0.004 & 0.001 & 0.006 & 0.005 & 0.003 & 0.001 & 0.004 & 0.001 \\
\hline$\sum$ Oct. & 2.843 & 0.138 & 2.888 & 0.161 & 2.955 & 0.171 & 2.840 & 0.043 & 2.865 & 0.212 & 2.852 & 0.150 & 2.713 & 0.046 & 2.647 & 0.042 \\
\hline Tetra./Oct. & 0.776 & 0.061 & 0.769 & 0.072 & 0.737 & 0.063 & 0.768 & 0.019 & 0.806 & 0.187 & 0.789 & 0.080 & 0.840 & 0.028 & 0.871 & 0.027 \\
\hline $\mathrm{Ni} / \mathrm{Mg}$ & 0.003 & 0.001 & 0.004 & 0.003 & 0.003 & 0.001 & 0.002 & 0.001 & 0.003 & 0.001 & 0.003 & 0.001 & 0.001 & 0.000 & 0.001 & 0.000 \\
\hline
\end{tabular}

$n$ total number of points acquired in polished thin section; $\sigma$ standard deviation of the analyzed points; apfu atoms per formula unit. 
In the saprock developed above lherzolite and harzburgite-dunite, the FeO content of type I, type II-rim and type II-core serpentines (average $5.62 \mathrm{wt} \%$, average $7.01 \mathrm{wt} \%$, average $7.75 \mathrm{wt} \%$ ) continuously increases (Tables 3 and 4). The FeO concentration of type III serpentines (average $6.42 \mathrm{wt} \%$ ) drops in the saprock. However, the amount of FeO in type IV serpentines (average $9.65 \mathrm{wt} \%$ ) increases again and finally decreases in type $\mathrm{V}$ serpentines (average $5.47 \mathrm{wt} \%$ ). Figure $11 \mathrm{a}, \mathrm{b}$ show that the $\mathrm{Fe} /(\mathrm{Fe}+\mathrm{Mg}+\mathrm{Ni})$ ratio increases from type I to type II serpentines and decreases in type III serpentines, but rises again in type IV serpentines. Finally, the $\mathrm{Fe} /(\mathrm{Fe}+\mathrm{Mg}+\mathrm{Ni})$ ratio declines in type $\mathrm{V}$ serpentines (Figure 11c). The $\mathrm{MgO}$ concentration from type I to type II serpentines (average $32.2 \mathrm{wt} \%$, average $33.68 \mathrm{wt} \%$, average $33.09 \mathrm{wt} \%$ ) increases, and subsequently decreases in type III and type IV serpentines (average $31.06 \mathrm{wt} \%$, average $29.84 \mathrm{wt} \%$ ). A similar trend is observed in $\mathrm{Mg} /(\mathrm{Mg}+\mathrm{Fe}+\mathrm{Ni})$ ratio from type I to type II serpentines, however, there is a significant decrease in the $\mathrm{Mg} /(\mathrm{Mg}+\mathrm{Fe}+$ $\mathrm{Ni}$ ) ratio of type III and type IV serpentines (Figure 11b). The saprock samples derived from lherzolite and harzburgite-dunite contain a low amount of $\mathrm{NiO}$ in type I serpentines (average $0.31 \mathrm{wt} \%$ ), type II-rim (average $0.25 \mathrm{wt} \%$ ), type II-core (average $0.26 \mathrm{wt} \%$ ), type III serpentines (average $0.07 \mathrm{wt} \%$ ) and type IV serpentines (average $0.11 \mathrm{wt} \%$ ). A significant amount of $\mathrm{NiO}$ is observed in type $\mathrm{V}$ serpentines (average $1.42 \mathrm{wt} \%$ ), particularly in the saprock derived from clinopyroxenite. Among the different types of serpentine in the saprock, a high $\mathrm{Ni} /(\mathrm{Ni}+\mathrm{Mg}+\mathrm{Fe})$ ratio is observed in type $\mathrm{V}$ serpentines (Figure 11c). The chemical composition of type $\mathrm{V}$ serpentines observed in the saprock plot near the serpentine-like garnierite of the $\mathrm{Si}-\mathrm{Mg}(+\mathrm{Fe})-\mathrm{Ni}$ ternary diagram (Figure 12). The average $\mathrm{O} / \mathrm{T}$ ratio $(\mathrm{Mg}+\mathrm{Fe}+\mathrm{Ni}) / \mathrm{Si})$ of type $\mathrm{V}$ serpentines is 0.94 , which is less than the ideal value $(\mathrm{O} / \mathrm{T}=1.5)$ of the serpentine group minerals.
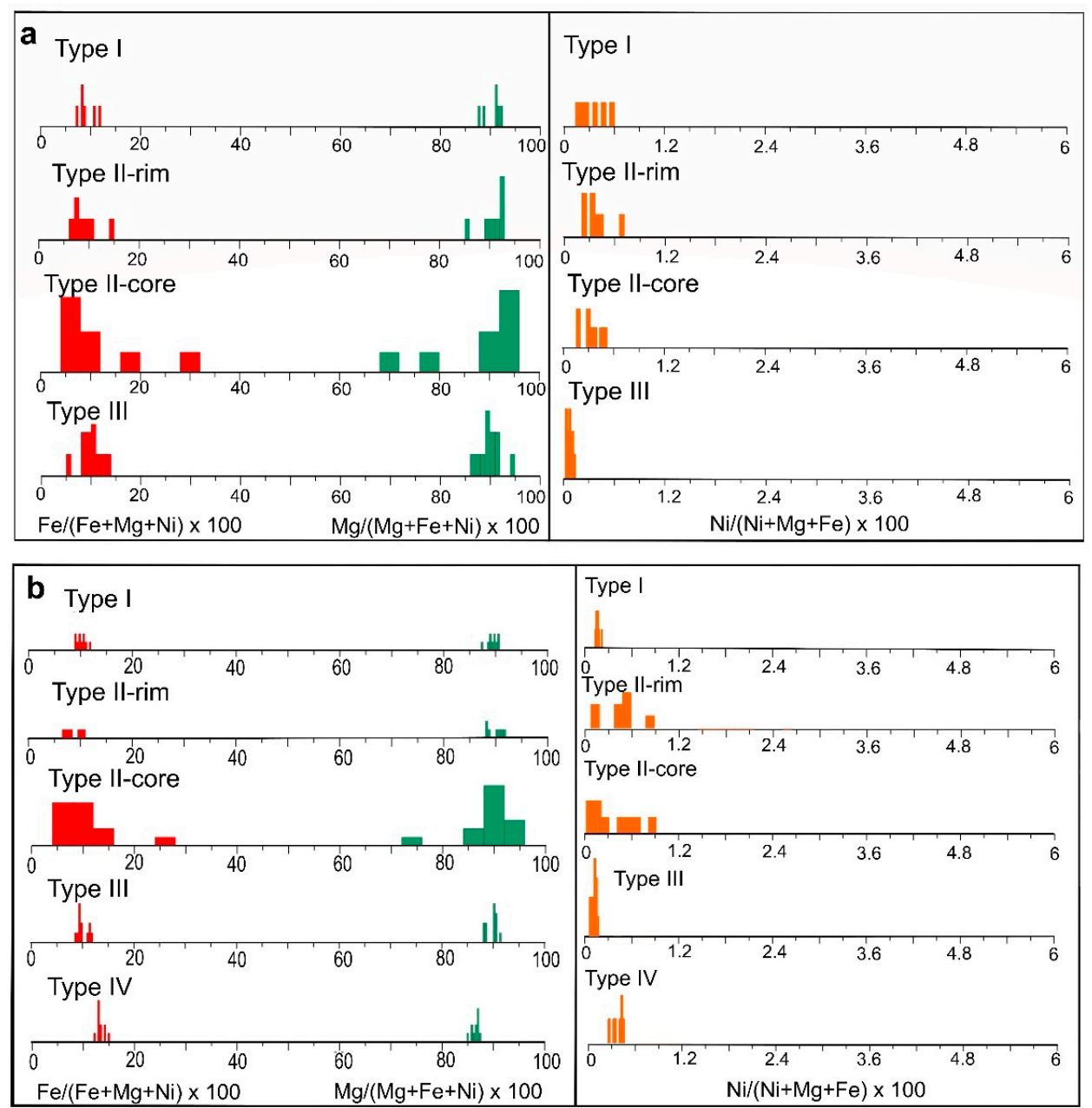

Figure 11. Cont. 


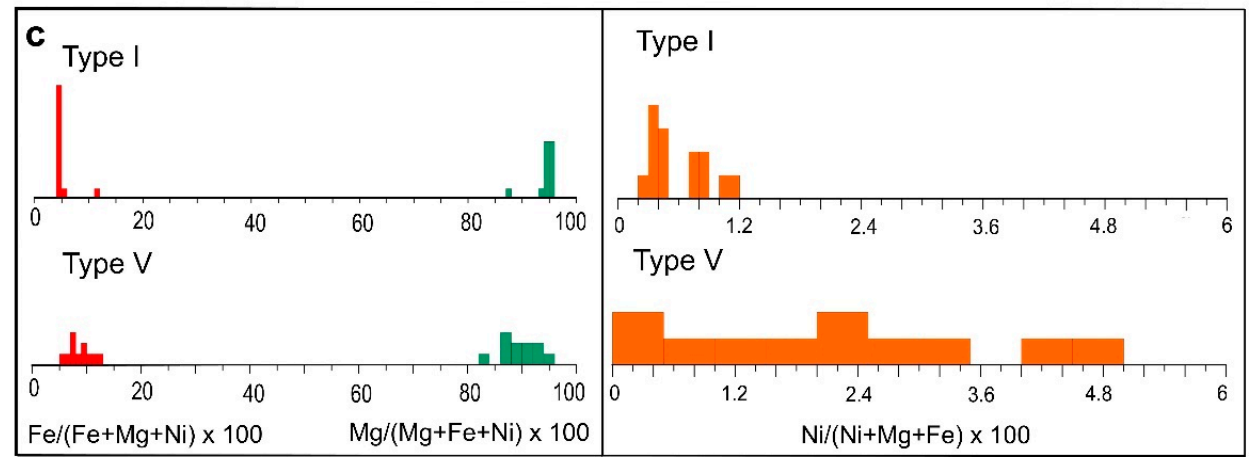

Figure 11. Histogram of $\mathrm{Mg}$ (green), $\mathrm{Fe}$ (red) and $\mathrm{Ni}$ (orange) mol ratio in the different types of serpentine identified in the saprock derived from (a) lherzolite (b) harzburgite-dunite and (c) clinopyroxenite bedrock.

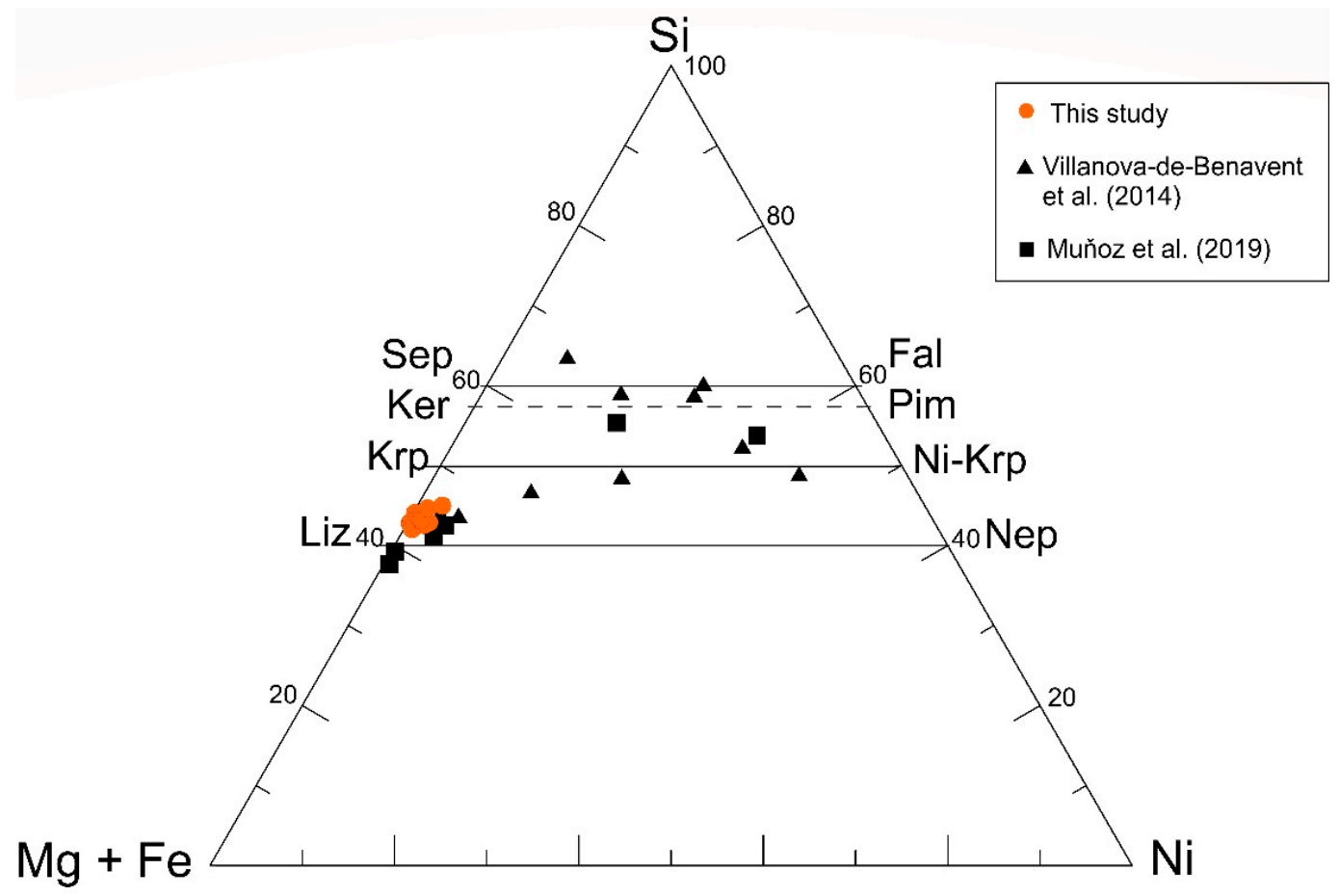

Figure 12. Si-Mg-(+Fe)-Ni plot showing the composition of serpentine-like garnierite in this study and previous works. Lz-lizardite, Nep-népouite, Krp-karpinskite, Ni-Krp-Ni-karpinskite, Ker-kerolite, Pim—pimelite, Sep—sepiolite, Fal—falcondoite.

Goethite contains a significant amount of $\mathrm{Al}_{2} \mathrm{O}_{3}$ (average $6.63 \mathrm{wt} \%$ ), $\mathrm{NiO}$ (average $0.77 \mathrm{wt} \%$ ), $\mathrm{MnO}$ (average $1.09 \mathrm{wt} \%$ ) and $\mathrm{CoO}$ (average $0.27 \mathrm{wt} \%$ ) (Table 5). In Figure 13a, the NiO concentration of goethite reaches up to $1.68 \mathrm{wt} \%$. The average structural formula of goethite is $\left(\mathrm{Fe}_{0.72}, \mathrm{Al}_{0.11}\right.$, $\left.\mathrm{Ni}_{0.01}, \mathrm{Mn}_{0.01}, \mathrm{Co}_{0.003}\right) \mathrm{O}(\mathrm{OH})$. Hematite is characterized by a considerable amount of $\mathrm{NiO}$ (average $0.38 \mathrm{wt} \%$ ), $\mathrm{CoO}$ (average $0.31 \mathrm{wt} \%$ ), $\mathrm{Al}_{2} \mathrm{O}_{3}$ (average $0.55 \mathrm{wt} \%$ ) and $\mathrm{MnO}$ (average $0.46 \mathrm{wt} \%$ ) (Figure $13 \mathrm{~b}$ ). The average structural formula of hematite is $\left(\mathrm{Fe}_{2.81}, \mathrm{Al}_{0.03}, \mathrm{Ni}_{0.01}, \mathrm{Mn}_{0.02}, \mathrm{Co}_{0.01}\right) \mathrm{O}_{3}$. The EPMA results show that talc contains a trace amount of $\mathrm{NiO}(0.10 \mathrm{wt} \%, 0.006 \mathrm{apfu} \mathrm{Ni})$ (Table 5). The average structural formula of talc is $\mathrm{Mg}_{2.56} \mathrm{Si}_{3.92} \mathrm{O}_{10}(\mathrm{OH})_{2}$. 
Table 3. Average chemical compositions ( $w \mathrm{t} \%$ ) and structural formula (apfu) of the different vein serpentines in the saprock.

\begin{tabular}{|c|c|c|c|c|c|c|c|c|c|c|c|c|}
\hline $\begin{array}{c}\text { Drill Core } \\
\text { Sample Name }\end{array}$ & $\begin{array}{l}\text { BB2515 } \\
\text { INT-D1-7 } \\
\text { Type I }\end{array}$ & $\sigma$ & $\begin{array}{l}\text { PG1500 } \\
\text { INT-D2-8 } \\
\text { Type I }\end{array}$ & $\sigma$ & $\begin{array}{c}\text { BB2515 } \\
\text { INT-D1-7 } \\
\text { Type II-rim }\end{array}$ & $\sigma$ & $\begin{array}{c}\text { BB2515 } \\
\text { INT-D1-7 } \\
\text { Type II-core }\end{array}$ & $\sigma$ & $\begin{array}{l}\text { BB2515 } \\
\text { INT-D1-7 } \\
\text { Type III } \\
\end{array}$ & $\sigma$ & $\begin{array}{l}\text { PG1500 } \\
\text { INT-D2-8 } \\
\text { Type V }\end{array}$ & $\sigma$ \\
\hline$n$ & 6 & & 14 & & 7 & & 8 & & 11 & & 11 & \\
\hline $\mathrm{SiO}_{2}$ & 39.49 & 2.44 & 42.08 & 1.67 & 39.41 & 2.79 & 39.84 & 3.31 & 44.28 & 4.75 & 40.92 & 1.25 \\
\hline $\mathrm{Al}_{2} \mathrm{O}_{3}$ & 0.69 & 1.37 & 1.40 & 1.09 & 0.01 & 0.02 & 0.01 & 0.01 & 0.89 & 0.38 & 0.04 & 0.03 \\
\hline $\mathrm{FeO}$ & 5.90 & 1.46 & 3.19 & 1.32 & 6.23 & 1.78 & 8.06 & 5.86 & 5.71 & 1.28 & 5.47 & 1.16 \\
\hline $\mathrm{MgO}$ & 32.21 & 1.63 & 32.86 & 0.95 & 34.27 & 1.87 & 32.77 & 2.63 & 28.56 & 1.52 & 31.81 & 2.21 \\
\hline $\mathrm{NiO}$ & 0.23 & 0.12 & 0.39 & 0.19 & 0.26 & 0.12 & 0.23 & 0.09 & 0.05 & 0.02 & 1.42 & 0.95 \\
\hline $\mathrm{CoO}$ & 0.02 & 0.01 & 0.01 & 0.01 & 0.02 & 0.01 & 0.03 & 0.03 & 0.01 & 0.01 & 0.02 & 0.02 \\
\hline $\mathrm{CaO}$ & 0.02 & 0.01 & 0.01 & 0.00 & 0.01 & 0.01 & 0.03 & 0.03 & 0.05 & 0.02 & 0.03 & 0.02 \\
\hline $\mathrm{Cr}_{2} \mathrm{O}_{3}$ & 0.03 & 0.04 & 0.21 & 0.28 & 0.00 & 0.01 & 0.01 & 0.01 & 0.29 & 0.13 & 0.02 & 0.01 \\
\hline $\mathrm{MnO}$ & 0.08 & 0.02 & 0.03 & 0.01 & 0.10 & 0.03 & 0.16 & 0.19 & 0.09 & 0.05 & 0.10 & 0.03 \\
\hline Total & 78.69 & 1.03 & 80.18 & 1.76 & 80.32 & 3.43 & 81.14 & 2.08 & 79.97 & 3.99 & 79.84 & 1.55 \\
\hline $\mathrm{Si}$ & 2.070 & 0.112 & 2.121 & 0.045 & 2.035 & 0.072 & 2.052 & 0.093 & 2.240 & 0.114 & 2.119 & 0.030 \\
\hline $\mathrm{Al}$ & 0.043 & 0.085 & 0.083 & 0.064 & 0.001 & 0.001 & 0.001 & 0.001 & 0.054 & 0.025 & 0.003 & 0.002 \\
\hline $\mathrm{Fe}$ & 0.259 & 0.067 & 0.135 & 0.060 & 0.272 & 0.088 & 0.356 & 0.275 & 0.243 & 0.055 & 0.238 & 0.054 \\
\hline$\sum$ Tetra. & 2.372 & 0.055 & 2.339 & 0.038 & 2.307 & 0.040 & 2.409 & 0.191 & 2.538 & 0.090 & 2.359 & 0.074 \\
\hline $\mathrm{Mg}$ & 2.519 & 0.149 & 2.469 & 0.062 & 2.640 & 0.071 & 2.518 & 0.130 & 2.168 & 0.189 & 2.453 & 0.128 \\
\hline $\mathrm{Ni}$ & 0.010 & 0.005 & 0.016 & 0.008 & 0.011 & 0.005 & 0.010 & 0.004 & 0.002 & 0.001 & 0.060 & 0.041 \\
\hline Co & 0.001 & 0.001 & 0.000 & 0.000 & 0.001 & 0.001 & 0.001 & 0.001 & 0.001 & 0.000 & 0.001 & 0.001 \\
\hline $\mathrm{Cr}$ & 0.001 & 0.002 & 0.008 & 0.011 & 0.000 & 0.000 & 0.000 & 0.000 & 0.012 & 0.006 & 0.001 & 0.001 \\
\hline $\mathrm{Ca}$ & 0.001 & 0.001 & 0.000 & 0.000 & 0.001 & 0.000 & 0.002 & 0.002 & 0.003 & 0.001 & 0.002 & 0.001 \\
\hline $\mathrm{Mn}$ & 0.004 & 0.001 & 0.001 & 0.000 & 0.004 & 0.002 & 0.007 & 0.009 & 0.004 & 0.002 & 0.005 & 0.001 \\
\hline$\sum$ Oct. & 2.536 & 0.151 & 2.495 & 0.052 & 2.657 & 0.077 & 2.538 & 0.118 & 2.189 & 0.192 & 2.521 & 0.098 \\
\hline Tetra./Oct. & 0.939 & 0.080 & 0.938 & 0.032 & 0.869 & 0.034 & 0.954 & 0.122 & 1.171 & 0.143 & 0.938 & 0.067 \\
\hline
\end{tabular}

$n$ total number of points acquired in polished thin section; $\sigma$ standard deviation of the analyzed points; apfu atoms per formula unit. 
Table 4. Average chemical compositions and structural formula (apfu) of the different veins serpentines in the saprock derived from harzburgite-dunite (wt\%).

\begin{tabular}{|c|c|c|c|c|c|c|c|c|c|c|}
\hline Drill Core & BB2406 & & BB2406 & & BB2406 & & BB2406 & & BB2406 & \\
\hline \multirow[t]{2}{*}{ Sample Name } & INT-D3-9 & & INT-D3-9 & & INT-D3-9 & & INT-D3-9 & & INT-D3-9 & \\
\hline & Type I & $\sigma$ & Type II-rim & $\sigma$ & Type II-core & $\sigma$ & Type III & $\sigma$ & Type IV & $\sigma$ \\
\hline$n$ & 10 & & 7 & & 13 & & 12 & & 11 & \\
\hline $\mathrm{SiO}_{2}$ & 36.92 & 1.27 & 39.92 & 1.44 & 37.15 & 5.86 & 38.94 & 0.93 & 39.12 & 0.52 \\
\hline $\mathrm{Al}_{2} \mathrm{O}_{3}$ & 0.00 & 0.00 & 0.04 & 0.05 & 0.06 & 0.13 & 0.42 & 0.13 & 0.13 & 0.04 \\
\hline $\mathrm{FeO}$ & 7.52 & 0.82 & 5.37 & 1.18 & 7.91 & 5.24 & 7.13 & 0.81 & 9.65 & 0.66 \\
\hline $\mathrm{MgO}$ & 37.22 & 0.72 & 38.58 & 0.75 & 37.78 & 1.41 & 35.83 & 1.22 & 34.94 & 0.80 \\
\hline $\mathrm{NiO}$ & 0.32 & 0.06 & 0.24 & 0.05 & 0.28 & 0.13 & 0.09 & 0.02 & 0.11 & 0.02 \\
\hline $\mathrm{CoO}$ & 0.03 & 0.01 & 0.01 & 0.01 & 0.03 & 0.03 & 0.02 & 0.01 & 0.03 & 0.02 \\
\hline $\mathrm{CaO}$ & 0.02 & 0.01 & 0.02 & 0.01 & 0.01 & 0.01 & 0.01 & 0.01 & 0.00 & 0.00 \\
\hline $\mathrm{Cr}_{2} \mathrm{O}_{3}$ & 0.00 & 0.01 & 0.01 & 0.01 & 0.01 & 0.02 & 0.47 & 0.12 & 0.01 & 0.00 \\
\hline $\mathrm{MnO}$ & 0.10 & 0.02 & 0.07 & 0.02 & 0.14 & 0.15 & 0.16 & 0.02 & 0.24 & 0.05 \\
\hline Total & 82.13 & 1.69 & 84.26 & 1.06 & 83.37 & 1.74 & 83.09 & 1.90 & 84.24 & 1.02 \\
\hline $\mathrm{Si}$ & 1.900 & 0.040 & 1.964 & 0.045 & 1.877 & 0.232 & 1.964 & 0.024 & 1.971 & 0.028 \\
\hline $\mathrm{Al}$ & 0.000 & 0.000 & 0.002 & 0.003 & 0.004 & 0.007 & 0.025 & 0.008 & 0.008 & 0.002 \\
\hline $\mathrm{Fe}$ & 0.324 & 0.033 & 0.222 & 0.051 & 0.350 & 0.283 & 0.301 & 0.034 & 0.407 & 0.028 \\
\hline$\sum$ Tetra. & 2.224 & 0.031 & 2.188 & 0.024 & 2.231 & 0.074 & 2.290 & 0.035 & 2.385 & 0.019 \\
\hline $\mathrm{Ni}$ & 0.013 & 0.002 & 0.010 & 0.002 & 0.012 & 0.007 & 0.004 & 0.001 & 0.005 & 0.001 \\
\hline Co & 0.001 & 0.000 & 0.001 & 0.000 & 0.001 & 0.001 & 0.001 & 0.000 & 0.001 & 0.001 \\
\hline $\mathrm{Cr}$ & 0.000 & 0.000 & 0.000 & 0.000 & 0.000 & 0.001 & 0.019 & 0.005 & 0.000 & 0.000 \\
\hline $\mathrm{Ca}$ & 0.001 & 0.000 & 0.001 & 0.000 & 0.001 & 0.000 & 0.001 & 0.000 & 0.000 & 0.000 \\
\hline $\mathrm{Mn}$ & 0.004 & 0.001 & 0.003 & 0.001 & 0.006 & 0.007 & 0.007 & 0.001 & 0.010 & 0.002 \\
\hline$\sum$ Oct. & 2.876 & 0.064 & 2.846 & 0.052 & 2.891 & 0.198 & 2.724 & 0.054 & 2.640 & 0.040 \\
\hline Tetra./Oct. & 0.774 & 0.026 & 0.769 & 0.020 & 0.774 & 0.050 & 0.841 & 0.028 & 0.904 & 0.020 \\
\hline
\end{tabular}


Table 5. Average compositions ( $w \mathrm{t} \%$ ) and structural formula (apfu) of goethite, hematite, and talc in the limonite samples.

\begin{tabular}{|c|c|c|c|c|c|c|c|c|c|c|c|}
\hline \multirow{4}{*}{$\begin{array}{c}\text { Drill Core } \\
\text { Sample Name } \\
\text { Depth, m }\end{array}$} & \multicolumn{4}{|c|}{ Goethite } & \multicolumn{6}{|c|}{ Hematite } & \multirow{4}{*}{$\begin{array}{c}\text { Talc } \\
\text { PG1500 } \\
\text { INT-D1-1 } \\
1\end{array}$} \\
\hline & \multirow{2}{*}{\multicolumn{2}{|c|}{$\begin{array}{l}\text { BB2515 } \\
\text { INT-D1-1 }\end{array}$}} & \multicolumn{2}{|c|}{ PG1500 } & \multicolumn{2}{|c|}{ BB2515 } & \multicolumn{2}{|c|}{ PG1500 } & \multicolumn{2}{|c|}{ BB2406 } & \\
\hline & & & INT-D & & INT-D & & INT-D & & INT-D & & \\
\hline & 1 & $\sigma$ & 1 & $\sigma$ & 1 & $\sigma$ & 1 & $\sigma$ & 2.4 & $\sigma$ & \\
\hline$n$ & 8 & & 10 & & 12 & & 5 & & 11 & & 1 \\
\hline $\mathrm{SiO}_{2}$ & 2.81 & 0.42 & 3.30 & 0.90 & 1.32 & 0.64 & 0.89 & 0.52 & 0.41 & 0.65 & 55.04 \\
\hline $\mathrm{MgO}$ & 0.37 & 0.24 & 0.62 & 0.50 & 0.50 & 0.25 & 0.56 & 0.60 & 0.27 & 0.09 & 24.07 \\
\hline $\mathrm{Al}_{2} \mathrm{O}_{3}$ & 6.47 & 2.48 & 6.79 & 2.30 & 1.46 & 0.60 & 0.10 & 0.12 & 0.08 & 0.12 & 1.53 \\
\hline $\mathrm{FeO}$ & 62.58 & 3.70 & 62.66 & 1.89 & 77.61 & 3.49 & 80.72 & 2.32 & 82.50 & 3.92 & 6.55 \\
\hline $\mathrm{NiO}$ & 0.79 & 0.38 & 0.76 & 0.35 & 0.24 & 0.08 & 0.41 & 0.76 & 0.13 & 0.08 & 0.10 \\
\hline $\mathrm{CoO}$ & 0.43 & 0.28 & 0.10 & 0.04 & 0.14 & 0.02 & 0.64 & 0.68 & 0.16 & 0.02 & 0.02 \\
\hline $\mathrm{Cr}_{2} \mathrm{O}_{3}$ & 0.34 & 0.24 & 0.96 & 0.68 & 0.89 & 0.35 & 0.08 & 0.05 & 0.10 & 0.09 & 0.17 \\
\hline $\mathrm{CaO}$ & 0.07 & 0.06 & 0.00 & 0.00 & 0.00 & 0.00 & 0.00 & 0.01 & 0.01 & 0.03 & 0.00 \\
\hline $\mathrm{MnO}$ & 1.78 & 1.22 & 0.39 & 0.30 & 0.15 & 0.06 & 1.04 & 0.95 & 0.19 & 0.24 & 0.04 \\
\hline Total & 75.69 & 3.22 & 75.81 & 3.16 & 82.34 & 3.45 & 84.46 & 2.52 & 83.88 & 3.86 & 87.56 \\
\hline $\mathrm{Fe}$ & 0.72 & 0.06 & 0.71 & 0.06 & 2.69 & 0.09 & 2.81 & 0.11 & 2.92 & 0.06 & \\
\hline $\mathrm{Al}$ & 0.10 & 0.04 & 0.11 & 0.03 & 0.07 & 0.03 & 0.01 & 0.01 & 0.00 & 0.01 & \\
\hline $\mathrm{Mn}$ & 0.02 & 0.01 & 0.00 & 0.00 & 0.01 & 0.00 & 0.04 & 0.03 & 0.01 & 0.01 & \\
\hline $\mathrm{Ni}$ & 0.01 & 0.00 & 0.01 & 0.00 & 0.01 & 0.00 & 0.01 & 0.02 & 0.00 & 0.00 & \\
\hline Co & 0.00 & 0.00 & 0.00 & 0.00 & 0.00 & 0.00 & 0.02 & 0.02 & 0.01 & 0.00 & \\
\hline
\end{tabular}

$n$ total number of points acquired in polished thin section; $\sigma$ standard deviation of the analyzed points; apfu atoms per formula unit.
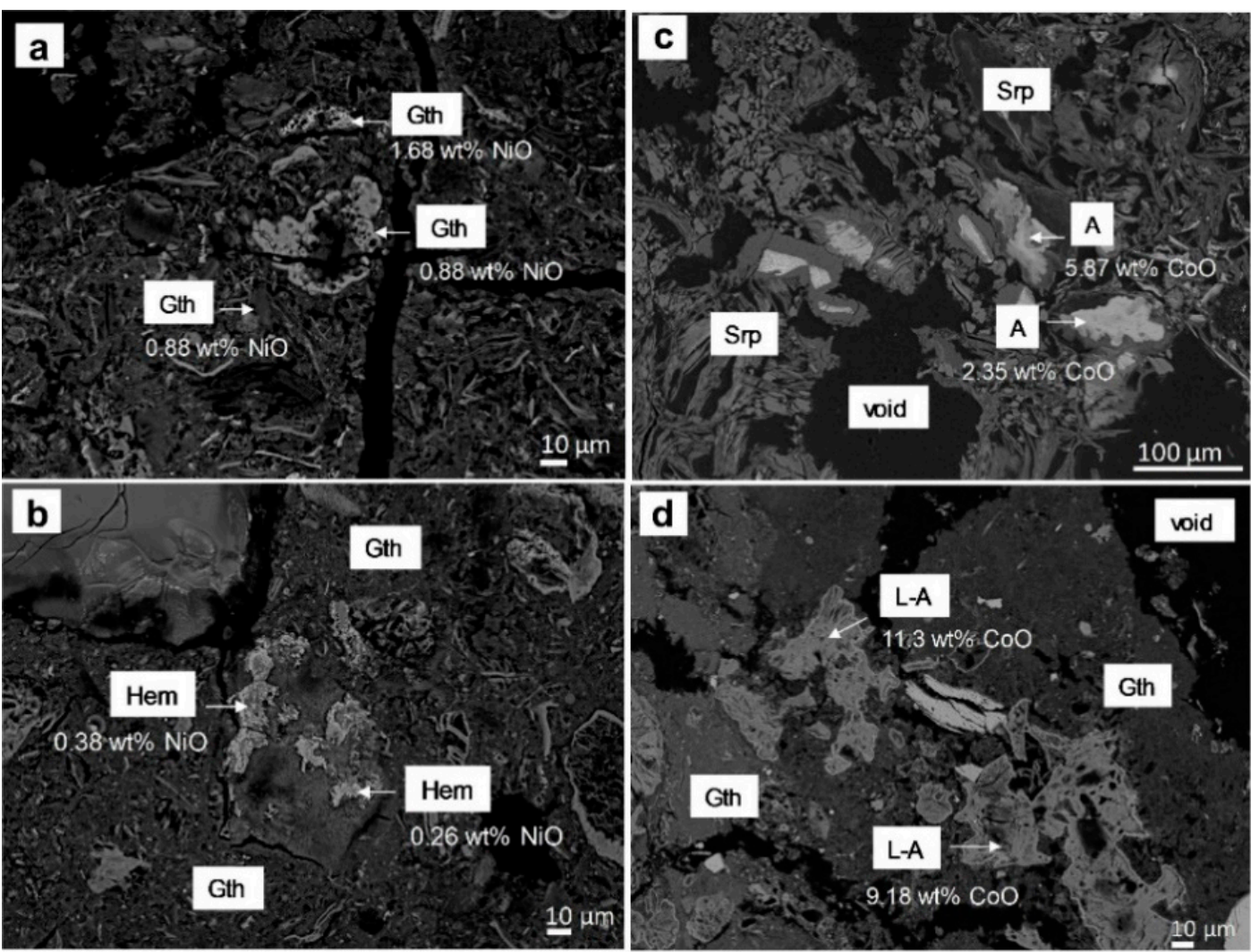

Figure 13. Backscattered electron images of (a) massive goethite (Gth) irregular aggregates of (b) hematite (Hem), (c) asbolane (A) in a serpentine (Srp) matrix and (d) lithiophorite-asbolane intermediate $(\mathrm{L}-\mathrm{A})$ in a goethite matrix.

Figure $13 \mathrm{c}, \mathrm{d}$ shows the occurrence of asbolane and lithiophorite-asbolane intermediate in the limonite. Based on the Ni-Co-Al ternary plot, these two phases are the major Co-bearing Mn-oxyhydroxides in the limonite samples (Figure 14). Asbolane is marked by high $\mathrm{NiO}$ and 
$\mathrm{CoO}$ concentrations of up to 12.89 and $3.82 \mathrm{wt} \%$. Furthermore, it contains a high amount of $\mathrm{FeO}$ and $\mathrm{MnO}$ (12.89 wt\%, 0.29 apfu $\mathrm{Fe} ; 32.17 \mathrm{wt} \%, 5.82 \mathrm{apfu} \mathrm{Mn)} \mathrm{(Table} \mathrm{6).} \mathrm{The} \mathrm{structural}$ formula of asbolane is $\left(\mathrm{Al}_{0.02} \mathrm{Ni}_{0.30} \mathrm{Co}_{0.09}\right)\left(\mathrm{Mn}_{0.80} \mathrm{Fe}_{0.23} \mathrm{Mg}_{0.26}\right) \mathrm{O}_{2}(\mathrm{OH})_{2}$. Lithiophorite-asbolane intermediate contains a high amount of $\mathrm{NiO}$ (average $3.00 \mathrm{wt} \%$ ), $\mathrm{CoO}$ (average $10.07 \mathrm{wt} \%$ ), $\mathrm{FeO}$ (average $10.72 \mathrm{wt} \%$ ), and $\mathrm{MnO}$ (average $39.21 \mathrm{wt} \%$ ). The calculated average formula is $\left(\mathrm{Al}_{0.20}, \mathrm{Ni}_{0.08}, \mathrm{Co}_{0.26}\right)\left(\mathrm{Mn}_{1.06}, \mathrm{Fe}_{0.29}, \mathrm{Mg}_{0.02}\right) \mathrm{O}_{2}(\mathrm{OH})_{2}$.

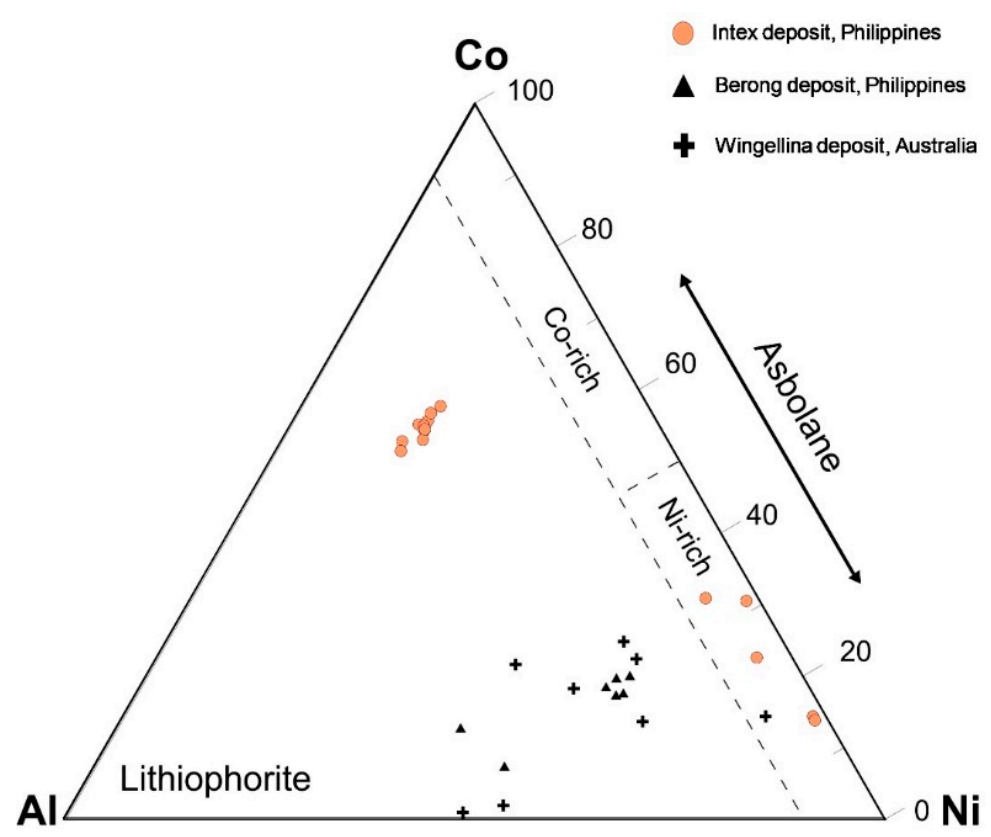

Figure 14. Co-Ni-Al ternary diagram ( $\mathrm{w} t \mathrm{t} \%$ ) displaying the mineralogy and composition of asbolane and lithiophorite-asbolane intermediate in the limonite horizon of the Intex deposit.

Table 6. Average chemical compositions (wt\%) and structural formula (apfu) of the representative. asbolane and lithiophorite-asbolane intermediate in the limonite horizon.

\begin{tabular}{|c|c|c|c|c|c|c|}
\hline \multirow{3}{*}{$\begin{array}{l}\text { Sample Name } \\
\text { Depth, m }\end{array}$} & \multirow{3}{*}{$\begin{array}{c}\text { Asbolane } \\
\text { INT-D1-4 } \\
4\end{array}$} & \multirow[b]{3}{*}{$\sigma$} & \multicolumn{4}{|c|}{ Lithiophorite-Asbolane Intermediate } \\
\hline & & & \multicolumn{2}{|l|}{ INT-D2-1 } & \multicolumn{2}{|c|}{ INT-D3-2 } \\
\hline & & & 1 & $\sigma$ & 2.4 & $\sigma$ \\
\hline$n$ & 5 & & 8 & & 3 & \\
\hline $\mathrm{SiO}_{2}$ & 5.95 & 8.92 & 0.03 & 0.02 & 0.04 & 0.05 \\
\hline $\mathrm{MgO}$ & 6.68 & 3.15 & 0.33 & 0.07 & 0.43 & 0.07 \\
\hline $\mathrm{Al}_{2} \mathrm{O}_{3}$ & 0.50 & 0.31 & 5.60 & 0.40 & 4.88 & 0.34 \\
\hline $\mathrm{FeO}$ & 9.64 & 1.97 & 8.66 & 2.36 & 12.79 & 11.00 \\
\hline $\mathrm{NiO}$ & 12.89 & 3.22 & 3.14 & 0.34 & 2.85 & 0.61 \\
\hline $\mathrm{CoO}$ & 3.82 & 1.53 & 10.43 & 1.07 & 9.72 & 2.20 \\
\hline $\mathrm{Cr}_{2} \mathrm{O}_{3}$ & 0.11 & 0.09 & 0.02 & 0.02 & 0.01 & 0.01 \\
\hline $\mathrm{CaO}$ & 0.95 & 1.69 & 0.06 & 0.02 & 0.08 & 0.03 \\
\hline $\mathrm{MnO}$ & 32.17 & 5.82 & 39.41 & 4.07 & 39.01 & 9.65 \\
\hline Total & 72.70 & 4.45 & 67.68 & 3.85 & 69.82 & 1.83 \\
\hline $\mathrm{Ni}$ & 0.305 & 0.108 & 0.081 & 0.005 & 0.072 & 0.014 \\
\hline $\mathrm{Al}$ & 0.016 & 0.010 & 0.213 & 0.009 & 0.182 & 0.008 \\
\hline Co & 0.089 & 0.046 & 0.269 & 0.014 & 0.245 & 0.050 \\
\hline $\mathrm{Mn}$ & 0.796 & 0.251 & 1.074 & 0.061 & 1.040 & 0.235 \\
\hline $\mathrm{Fe}$ & 0.230 & 0.063 & 0.237 & 0.079 & 0.343 & 0.304 \\
\hline $\mathrm{Mg}$ & 0.265 & 0.056 & 0.016 & 0.003 & 0.020 & 0.003 \\
\hline $\mathrm{Co} / \mathrm{Ni}$ & 0.316 & 0.152 & 3.317 & 0.161 & 3.388 & 0.062 \\
\hline
\end{tabular}

$n$ total number of points acquired in polished thin section; $\sigma$ standard deviation of the analyzed points; apfu atoms per formula unit. 


\section{5. $\mathrm{pH}$, Petrographic and Whole-Rock Geochemical Analysis}

Figures 15-17 illustrate the relative amount of olivine, variations in $\mathrm{pH}$ and elements in representative bedrock, saprolite, and limonite samples. The $\mathrm{pH}$ of these samples is between 6.14 and 8.75. A pH gradient displays the shift from alkaline condition ( $\mathrm{pH} 8.75$ ) in the bedrock to neutral condition ( $\mathrm{pH} 7.32$ ) in the saprolite horizon to mildly acidic conditions ( $\mathrm{pH} 6.14)$ in the limonite horizon.

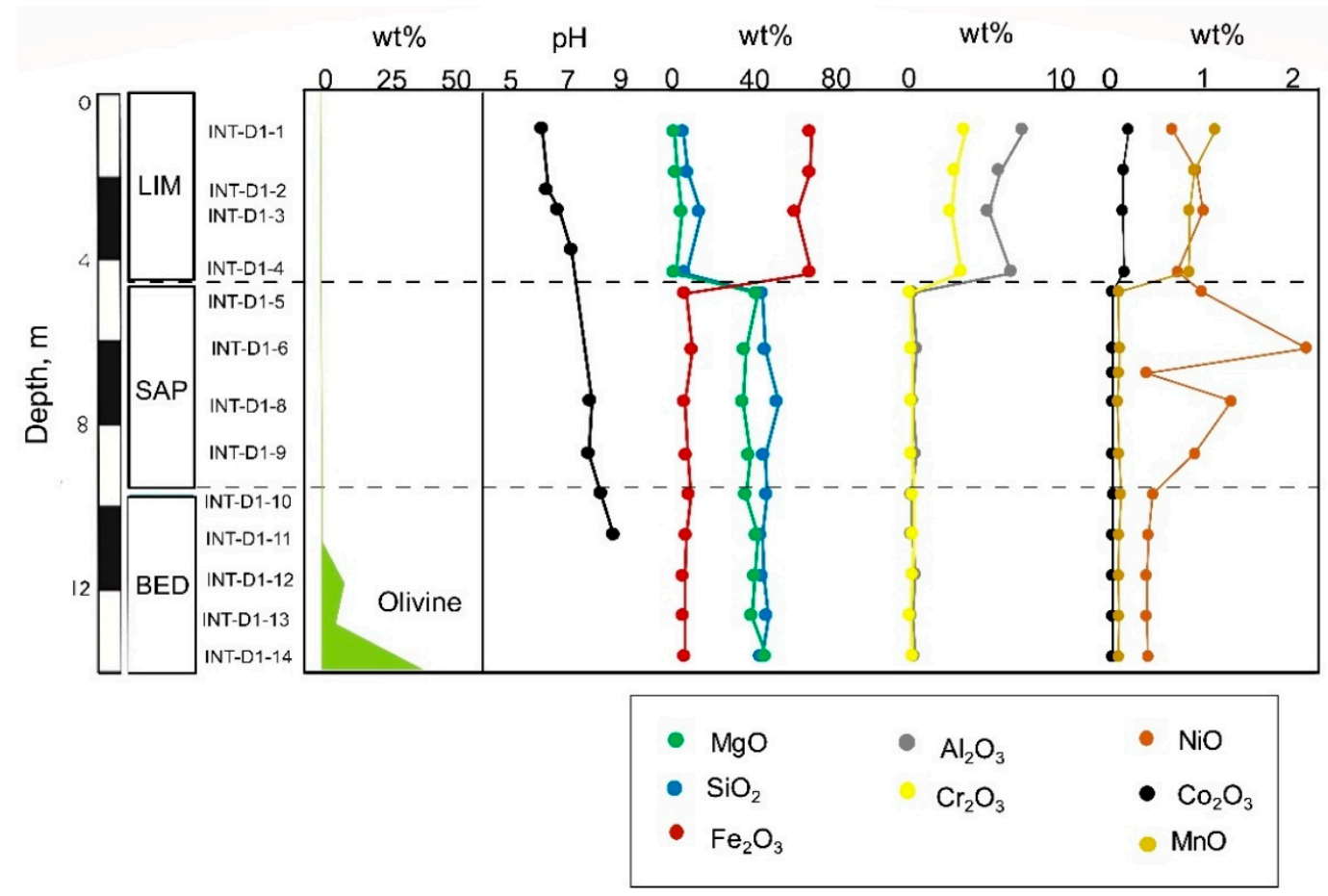

Figure 15. Distribution of olivine, $\mathrm{pH}$ and elements with depth in the laterite derived from lherzolite bedrock (BB2515 core).

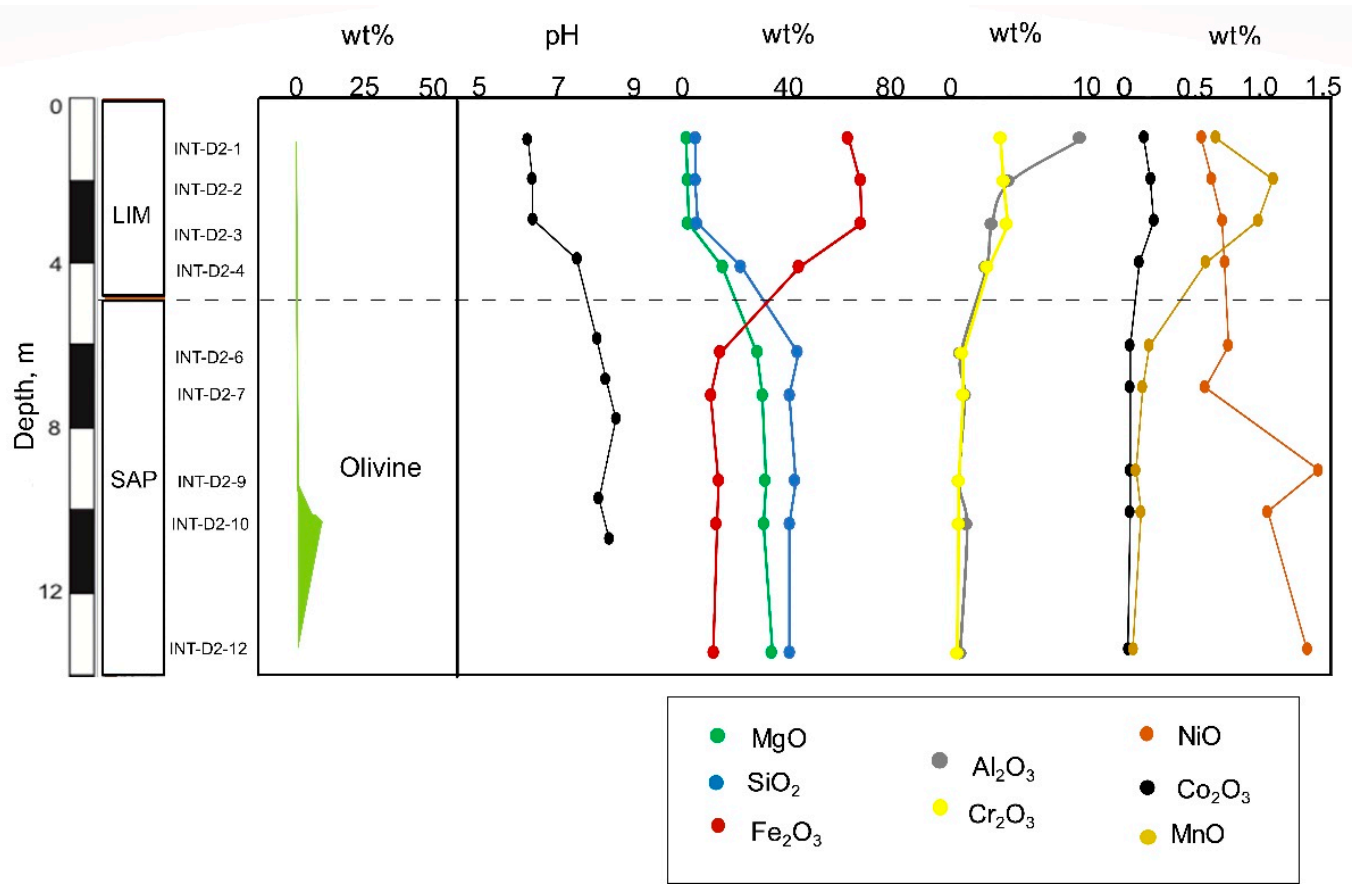

Figure 16. Distribution of olivine, $\mathrm{pH}$ and elements with depth in the laterite derived from clinopyroxenite bedrock (PG1500 core). 


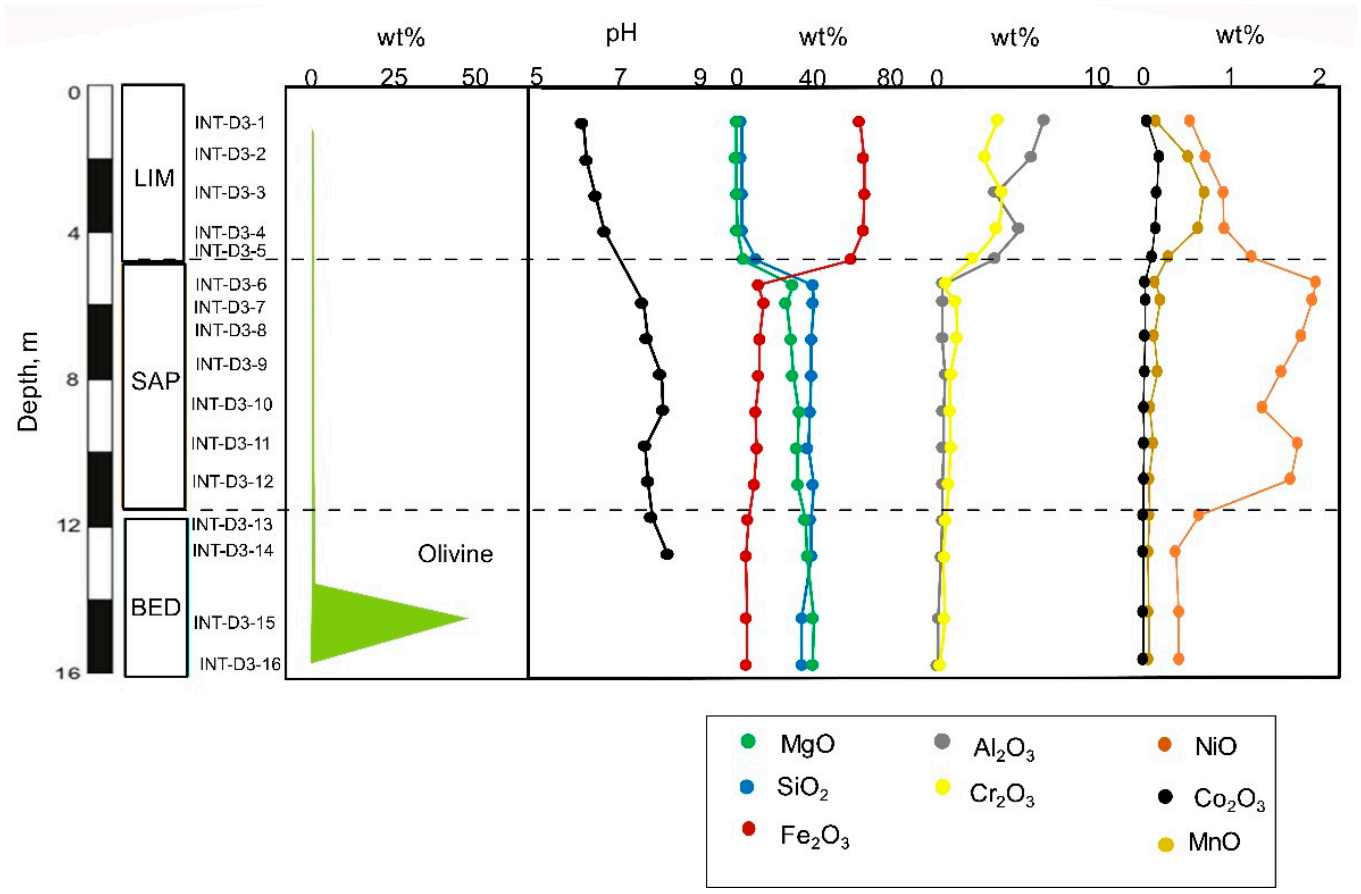

Figure 17. Distribution of olivine, $\mathrm{pH}$ and elements with depth in the laterite derived from harzburgite-dunite bedrock (BB2406 core).

The different types of bedrock contain high amounts of $\mathrm{MgO}$ (up to $41.96 \mathrm{wt} \%$ ) and $\mathrm{SiO}_{2}$ (up to $42.73 \mathrm{wt} \%$ ), and low concentration of $\mathrm{Fe}_{2} \mathrm{O}_{3}(6.63 \mathrm{wt} \%)$ (Tables 7-9). Figures $15-17$ show a sudden decrease in $\mathrm{MgO}$ and $\mathrm{SiO}_{2}$ concentrations (2.09 $\mathrm{wt} \%, 5.49 \mathrm{wt} \%$ ) in the transition boundary between the saprolite and limonite horizons. In contrast, the $\mathrm{Fe}_{2} \mathrm{O}_{3}$ content sharply increases from this boundary towards the limonite horizon (up to $67.58 \mathrm{wt} \%$ ). In this horizon, relatively high concentrations of $\mathrm{Al}_{2} \mathrm{O}_{3}$ and $\mathrm{Cr}_{2} \mathrm{O}_{3}$ (up to $9.29 \mathrm{wt} \%, 3.93 \mathrm{wt} \%$ ) are observed.

The saprolite horizon is marked by a high $\mathrm{NiO}$ concentration, which reaches up to $2.15 \mathrm{wt} \%$. The bedrock shows low $\mathrm{CoO}$ and $\mathrm{MnO}$ contents $(0.01 \mathrm{wt} \%, 0.07 \mathrm{wt} \%)$, whereas significant amounts of these elements are found in the limonite horizon (up to $0.19 \mathrm{wt} \%, 1.15 \mathrm{wt} \%$ ). The concentrations of $\mathrm{TiO}_{2}, \mathrm{~K}_{2} \mathrm{O}, \mathrm{CaO}$, and $\mathrm{P}_{2} \mathrm{O}_{5}$ in the bedrock are either low or below the detection limits. Conversely, the limonite horizon contains a considerable amount of $\mathrm{TiO}_{2}$ and $\mathrm{CaO}$ (up to $0.35 \mathrm{wt} \%, 1.15 \mathrm{wt} \%$ ). 
Table 7. Whole-rock chemical analyses (wt\%) of the bedrock (BED), saprolite (SAP), and limonite (LIM) samples through BB2515 core.

\begin{tabular}{|c|c|c|c|c|c|c|c|c|c|c|c|c|c|}
\hline $\begin{array}{l}\text { Drill Core } \\
\text { Horizon } \\
\text { Depth, m }\end{array}$ & $\begin{array}{c}\text { BB2515 } \\
1 \\
\text { LIM }\end{array}$ & $\begin{array}{c}\text { BB2515 } \\
2 \\
\text { LIM }\end{array}$ & $\begin{array}{c}\text { BB2515 } \\
3 \\
\text { LIM }\end{array}$ & $\begin{array}{c}\text { BB2515 } \\
5 \\
\text { LIM-SAP }\end{array}$ & $\begin{array}{c}\text { BB2515 } \\
5 \\
\text { SAP }\end{array}$ & $\begin{array}{c}\text { BB2515 } \\
6 \\
\text { SAP }\end{array}$ & $\begin{array}{c}\text { BB2515 } \\
8 \\
\text { SAP }\end{array}$ & $\begin{array}{c}\text { BB2515 } \\
9 \\
\text { SAP }\end{array}$ & $\begin{array}{c}\text { BB2515 } \\
10 \\
\text { BED }\end{array}$ & $\begin{array}{c}\text { BB2515 } \\
11 \\
\text { BED }\end{array}$ & $\begin{array}{c}\text { BB2515 } \\
12 \\
\text { BED }\end{array}$ & $\begin{array}{c}\text { BB2515 } \\
13 \\
\text { BED }\end{array}$ & $\begin{array}{c}\text { BB2515 } \\
14 \\
\text { BED }\end{array}$ \\
\hline $\mathrm{Na}_{2} \mathrm{O}$ & $\mathrm{bdl}$ & bdl & bdl & $\mathrm{bdl}$ & bdl & $\mathrm{bdl}$ & bdl & bdl & bdl & $\mathrm{bdl}$ & bdl & $\mathrm{bdl}$ & $\mathrm{bdl}$ \\
\hline $\mathrm{SiO}_{2}$ & 6.41 & 8.54 & 13.76 & 7.56 & 40.59 & 41.82 & 47.07 & 41.57 & 42.39 & 40.13 & 40.72 & 42.73 & 39.99 \\
\hline $\mathrm{Al}_{2} \mathrm{O}_{3}$ & 7.363 & 5.906 & 5.202 & 6.631 & 0.488 & 0.783 & 0.487 & 0.719 & 0.410 & 0.468 & 0.678 & 0.472 & 0.636 \\
\hline $\mathrm{P}_{2} \mathrm{O}_{5}$ & 0.010 & 0.005 & 0.006 & 0.007 & bdl & bdl & bdl & bdl & bdl & bdl & bdl & bdl & bdl \\
\hline $\mathrm{K}_{2} \mathrm{O}$ & 0.011 & 0.007 & 0.009 & 0.010 & 0.003 & 0.003 & 0.007 & 0.004 & 0.003 & 0.006 & 0.002 & 0.003 & 0.002 \\
\hline $\mathrm{TiO}_{2}$ & 0.115 & 0.087 & 0.077 & 0.115 & bdl & bdl & 0.005 & 0.008 & 0.006 & 0.005 & bdl & bdl & bdl \\
\hline $\mathrm{Cr}_{2} \mathrm{O}_{3}$ & 3.729 & 3.153 & 2.870 & 3.540 & 0.375 & 0.455 & 0.443 & 0.458 & 0.553 & 0.553 & 0.512 & 0.372 & 0.490 \\
\hline $\mathrm{MnO}$ & 1.148 & 0.917 & 0.863 & 0.859 & 0.080 & 0.091 & 0.072 & 0.085 & 0.109 & 0.084 & 0.078 & 0.084 & 0.081 \\
\hline $\mathrm{Fe}_{2} \mathrm{O}_{3}$ & 61.277 & 60.966 & 54.806 & 61.325 & 7.290 & 10.416 & 7.037 & 8.050 & 9.274 & 7.854 & 6.876 & 6.676 & 6.998 \\
\hline $\mathrm{Co}_{2} \mathrm{O}_{3}$ & 0.191 & 0.133 & 0.129 & 0.142 & 0.013 & 0.014 & 0.012 & 0.014 & 0.018 & 0.013 & 0.011 & 0.013 & 0.013 \\
\hline $\mathrm{NiO}$ & 0.675 & 0.938 & 1.014 & 0.730 & 1.000 & 2.153 & 1.327 & 0.919 & 0.461 & 0.410 & 0.388 & 0.390 & 0.405 \\
\hline LOI & 12.55 & 11.48 & 10.61 & 12.18 & 10.55 & 9.37 & 10.32 & 11.58 & 11.96 & 11.31 & 12.20 & 12.05 & 7.059 \\
\hline Total & 96.10 & 95.83 & 96.37 & 96.18 & 98.86 & 98.73 & 98.83 & 98.75 & 98.84 & 99.42 & 98.90 & 98.76 & 98.21 \\
\hline
\end{tabular}


Table 8. Whole-rock chemical analyses (wt \%) of the bedrock (BED), saprolite (SAP), and limonite (LIM) samples through PG1500 core.

\begin{tabular}{|c|c|c|c|c|c|c|c|c|c|c|}
\hline Drill Core & PG1500 & PG1500 & PG1500 & PG1500 & PG1500 & PG1500 & PG1500 & PG1500 & PG1500 & PG1500 \\
\hline Horizon & 1 & 2 & 3.0 & 3.8 & 4 & 6 & 7 & 9 & 10 & 13.3 \\
\hline Depth, m & LIM & LIM & LIM & LIM & LIM-SAP & SAP & SAP & SAP & SAP & SAP \\
\hline $\mathrm{Na}_{2} \mathrm{O}$ & 0.049 & $\mathrm{bdl}$ & $\mathrm{bdl}$ & bdl & 0.051 & bdl & 0.04 & 0.08 & bdl & bdl \\
\hline $\mathrm{MgO}$ & 1.348 & 2.016 & 2.093 & 24.02 & 14.92 & 28.10 & 29.92 & 31.11 & 30.47 & 32.94 \\
\hline $\mathrm{SiO}_{2}$ & 4.879 & 4.861 & 5.486 & 29.86 & 21.96 & 43.27 & 40.01 & 42.23 & 40.07 & 40.06 \\
\hline $\mathrm{Al}_{2} \mathrm{O}_{3}$ & 9.286 & 4.214 & 2.972 & 1.601 & 2.585 & 0.763 & 1.045 & 0.648 & 1.220 & 0.706 \\
\hline $\mathrm{P}_{2} \mathrm{O}_{5}$ & 0.015 & 0.005 & bdl & 0.003 & 0.009 & bdl & bdl & bdl & bdl & 0.003 \\
\hline $\mathrm{K}_{2} \mathrm{O}$ & 0.043 & 0.012 & 0.009 & 0.005 & 0.042 & 0.006 & 0.010 & 0.018 & 0.006 & 0.002 \\
\hline $\mathrm{CaO}$ & 0.040 & bdl & bdl & 0.078 & 0.122 & 0.317 & 0.339 & 0.906 & 1.293 & 0.153 \\
\hline $\mathrm{TiO}_{2}$ & 0.345 & 0.081 & 0.058 & 0.021 & 0.047 & 0.010 & 0.011 & 0.011 & 0.009 & 0.007 \\
\hline $\mathrm{Cr}_{2} \mathrm{O}_{3}$ & 3.597 & 3.812 & 4.077 & 1.552 & 2.700 & 0.872 & 0.919 & 0.600 & 0.614 & 0.693 \\
\hline $\mathrm{MnO}$ & 0.694 & 1.139 & 1.022 & 0.430 & 0.618 & 0.177 & 0.126 & 0.075 & 0.114 & 0.050 \\
\hline $\mathrm{Fe}_{2} \mathrm{O}_{3}$ & 62.08 & 66.60 & 66.98 & 30.11 & 43.81 & 14.07 & 10.71 & 13.43 & 12.78 & 12.22 \\
\hline $\mathrm{Co}_{2} \mathrm{O}_{3}$ & 0.135 & 0.189 & 0.212 & 0.067 & 0.101 & 0.030 & 0.030 & 0.030 & 0.030 & 0.011 \\
\hline $\mathrm{NiO}$ & 0.584 & 0.664 & 0.743 & 0.696 & 0.765 & 0.793 & 0.613 & 1.492 & 1.098 & 1.406 \\
\hline LOI & 13.66 & 11.89 & 11.94 & 11.29 & 10.89 & 10.12 & 18.05 & 9.23 & 8.77 & 11.46 \\
\hline Total & 96.76 & 95.51 & 95.61 & 99.76 & 98.62 & 98.54 & 101.8 & 99.86 & 96.50 & 99.66 \\
\hline
\end{tabular}

bdl-below detection limit. 
Table 9. Whole-rock chemical analyses (wt\%) of the bedrock (BED), saprolite (SAP), and limonite (LIM) samples through BB2406 core.

\begin{tabular}{|c|c|c|c|c|c|c|c|c|c|c|c|c|c|c|c|c|}
\hline $\begin{array}{c}\text { Drill Core } \\
\text { Sample Name } \\
\text { Depth, } m\end{array}$ & $\begin{array}{c}\text { BB2406 } \\
1 \\
\text { LIM }\end{array}$ & $\begin{array}{c}\text { BB2406 } \\
2 \\
\text { LIM }\end{array}$ & $\begin{array}{c}\text { BB2406 } \\
3 \\
\text { LIM }\end{array}$ & $\begin{array}{c}\text { BB2406 } \\
4 \\
\text { LIM }\end{array}$ & $\begin{array}{c}\text { BB2406 } \\
4.8 \\
\text { LIM-SAP }\end{array}$ & $\begin{array}{l}\text { BB2406 } \\
5.5 \\
\text { SAP }\end{array}$ & $\begin{array}{c}\text { BB2406 } \\
6 \\
\text { SAP }\end{array}$ & $\begin{array}{c}\text { BB2406 } \\
7 \\
\text { SAP }\end{array}$ & $\begin{array}{c}\text { BB2406 } \\
8 \\
\text { SAP }\end{array}$ & $\begin{array}{c}\text { BB2406 } \\
9 \\
\text { SAP }\end{array}$ & $\begin{array}{c}\text { BB2406 } \\
10 \\
\text { SAP }\end{array}$ & $\begin{array}{l}\text { BB2406 } \\
11 \\
\text { SAP }\end{array}$ & $\begin{array}{c}\text { BB2406 } \\
12 \\
\text { SAP }\end{array}$ & $\begin{array}{c}\text { BB2406 } \\
13 \\
\text { BED }\end{array}$ & $\begin{array}{c}\text { BB2406 } \\
15 \\
\text { BED }\end{array}$ & $\begin{array}{c}\text { BB2406 } \\
16 \\
\text { BED }\end{array}$ \\
\hline $\mathrm{Na}_{2} \mathrm{O}$ & bdl & bdl & bdl & bdl & bdl & bdl & bdl & bdl & bdl & bdl & bdl & bdl & bdl & bdl & bdl & bdl \\
\hline $\mathrm{MgO}, \%$ & 1.655 & 1.404 & 1.708 & 1.849 & 5.183 & 30.75 & 27.17 & 29.58 & 30.73 & 33.97 & 32.81 & 33.33 & 37.13 & 38.06 & 41.39 & 40.78 \\
\hline $\mathrm{SiO}_{2}, \%$ & 4.055 & 4.129 & 4.263 & 4.355 & 11.91 & 40.76 & 41.22 & 40.12 & 40.07 & 39.35 & 38.47 & 41.34 & 40.02 & 40.25 & 35.33 & 35.31 \\
\hline $\mathrm{K}_{2} \mathrm{O}, \%$ & 0.013 & bdl & bdl & bdl & 0.014 & 0.009 & 0.005 & $\mathrm{bdl}$ & bdl & bdl & bdl & bdl & bdl & bdl & bdl & bdl \\
\hline $\mathrm{CaO}, \%$ & 0.022 & 0.017 & 0.014 & 0.019 & 0.374 & -0.001 & 0.037 & 0.007 & 0.155 & 0.181 & 0.085 & 0.233 & 0.150 & 0.350 & 0.060 & 0.049 \\
\hline $\mathrm{Al}_{2} \mathrm{O}_{3}, \%$ & 6.773 & 6.000 & 3.752 & 5.264 & 3.692 & 0.457 & 0.479 & 0.465 & 0.627 & 0.491 & 0.521 & 0.441 & 0.472 & 0.370 & 0.203 & 0.139 \\
\hline $\mathrm{P}_{2} \mathrm{O}_{5}, \%$ & 0.013 & 0.005 & 0.003 & 0.005 & 0.007 & 0.007 & 0.003 & 0.002 & 0.003 & 0.001 & 0.003 & 0.004 & 0.000 & 0.001 & 0.000 & 0.001 \\
\hline $\mathrm{TiO}_{2}, \%$ & 0.129 & 0.083 & 0.076 & 0.067 & 0.105 & 0.006 & 0.008 & 0.006 & 0.006 & 0.006 & bdl & 0.007 & bdl & bdl & bdl & bdl \\
\hline $\mathrm{Cr}_{2} \mathrm{O}_{3}$ & 3.925 & 3.136 & 4.133 & 3.838 & 2.366 & 0.675 & 1.280 & 1.364 & 0.972 & 0.951 & 0.967 & 0.857 & 0.691 & 0.529 & 0.605 & 0.290 \\
\hline $\mathrm{MnO}, \%$ & 0.151 & 0.522 & 0.710 & 0.644 & 0.295 & 0.146 & 0.207 & 0.139 & 0.176 & 0.092 & 0.125 & 0.078 & 0.086 & 0.069 & 0.077 & 0.075 \\
\hline $\mathrm{Fe}_{2} \mathrm{O}_{3}, \%$ & 65.21 & 67.09 & 67.58 & 66.79 & 60.43 & 12.92 & 15.69 & 13.69 & 13.11 & 11.52 & 12.10 & 10.77 & 7.694 & 6.625 & 7.026 & 6.827 \\
\hline $\mathrm{Co}_{2} \mathrm{O}_{3}, \%$ & 0.053 & 0.192 & 0.170 & 0.155 & 0.112 & 0.034 & 0.037 & 0.032 & 0.029 & 0.021 & 0.024 & 0.016 & 0.014 & 0.012 & 0.015 & 0.015 \\
\hline $\mathrm{NiO}, \%$ & 0.547 & 0.726 & 0.925 & 0.938 & 1.246 & 1.985 & 1.940 & 1.810 & 1.584 & 1.367 & 1.776 & 1.693 & 0.655 & 0.383 & 0.421 & 0.421 \\
\hline LOI & 13.83 & 13.31 & 11.77 & 11.49 & 10.99 & 11.49 & 11.06 & 11.79 & 11.45 & 11.13 & 12.43 & 10.38 & 12.45 & 12.49 & 13.89 & 15.38 \\
\hline Total & 96.35 & 96.59 & 95.08 & 95.38 & 96.71 & 99.15 & 99.05 & 98.99 & 98.88 & 99.08 & 99.31 & 99.12 & 99.30 & 99.10 & 98.99 & 99.26 \\
\hline
\end{tabular}

bdl—below detection limit. 


\section{Discussion}

\subsection{Mineralogical Evolution of the Laterite Profiles}

The $\mathrm{NiO}$ concentration of olivine $(0.37 \mathrm{wt} \%)$, orthopyroxene $(0.07 \mathrm{wt} \%)$, clinopyroxene $(0.04 \mathrm{wt} \%)$, and talc $(0.07 \mathrm{wt} \%)$ (Table 1$)$ indicate that olivine is the major source of $\mathrm{Ni}$ in the saprolite and limonite horizons. The initial serpentinization of peridotite and pyroxenite results in the formation of type I serpentines. Continuous serpentinization leads to the formation of type II-rim serpentine veins, which is followed by type II-core and later by type III veins in the studied bedrock (Figure 18). This sequence is identical in the bedrock and saprock, suggesting a similar generation of serpentinization.

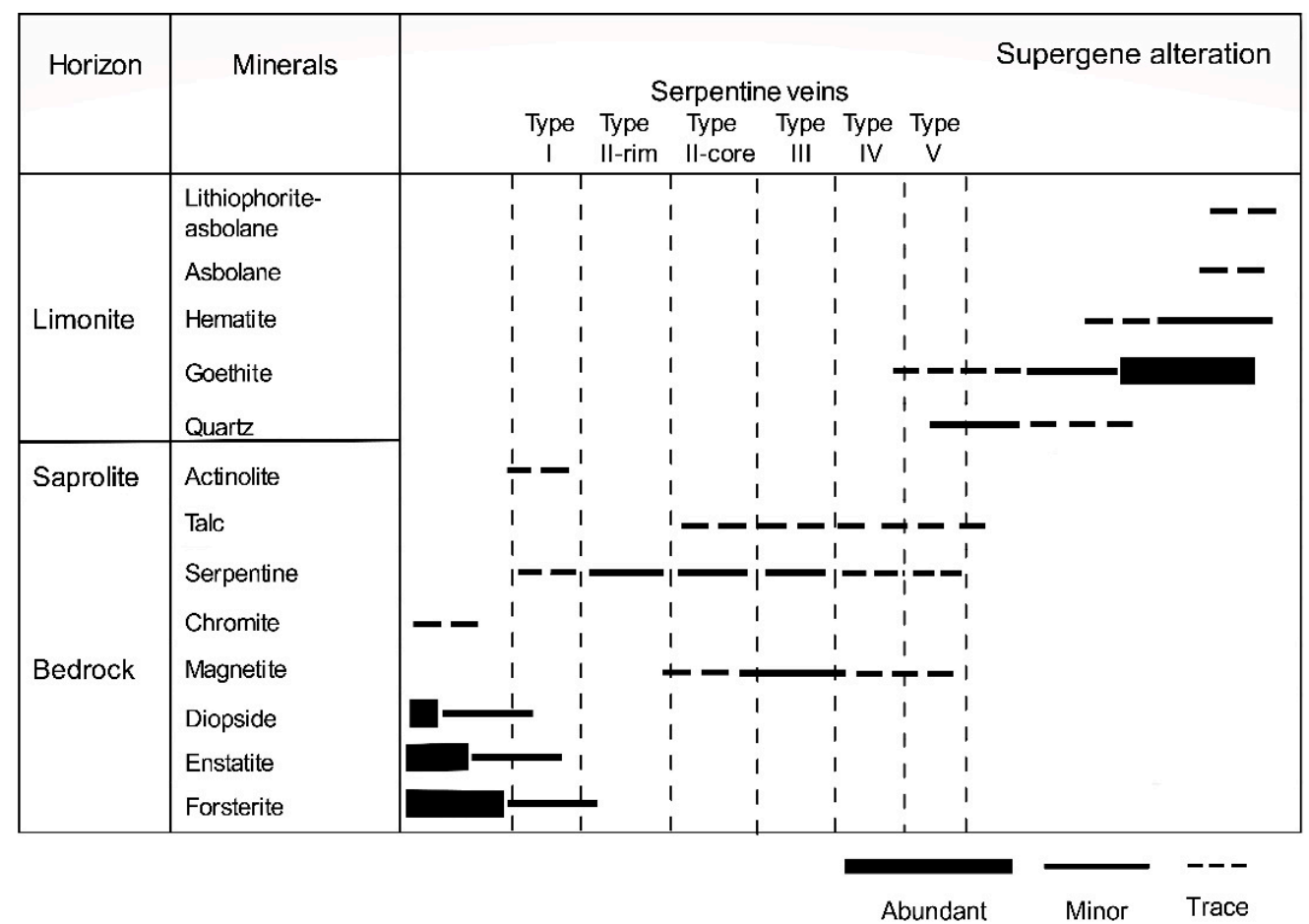

Figure 18. Mineral paragenesis and abundance of primary and alteration minerals with Ni-bearing serpentine veins in the bedrock and saprock of the Intex laterite deposit in Mindoro, Philippines.

The Raman characterization of type I, type II, and type III serpentines in the lherzolite and harzburgite-mdunite identified the types as lizardite, whereas type I serpentines in the clinopyroxenite were identified as antigorite. The serpentine variety can be explained by the difference in the pressure and temperature conditions to which they were subjected. Lizardite and chrysotile form predominantly in a low-temperature $\left(<300^{\circ} \mathrm{C}\right)$ - pressure condition, whereas antigorite forms in a high-temperature $\left(>320^{\circ} \mathrm{C}\right.$ )- pressure condition $[40,41]$. Type I to type III serpentines found in the ultramafic bedrock are of hydrothermal origin, which is formed before its settlement and exposure on the surface. Although we have not confirmed the replacement texture of lizardite by antigorite, the formation of lizardite in type I veins can be explained by the reaction of olivine and water (Equation (1)), in addition to the development of magnetite after the breakdown of brucite (Equation (2)) and serpentine (Equation (3)) [42-44].

$$
\begin{gathered}
2(\mathrm{Mg}, \mathrm{Fe})_{2} \mathrm{SiO}_{4} \text { (olivine) }+3 \mathrm{H}_{2} \mathrm{O}(\text { water })=(\mathrm{Mg}, \mathrm{Fe})_{3} \mathrm{Si}_{2} \mathrm{O}_{5}(\mathrm{OH})_{4} \text { (serpentine) }+ \\
(\mathrm{Mg}, \mathrm{Fe})(\mathrm{OH})_{2} \text { (brucite) } \\
9 \mathrm{Fe}(\mathrm{OH})_{2} \text { (brucite) }+4 \mathrm{SiO}_{2}(\text { silica })=2 \mathrm{Fe}_{3} \mathrm{Si}_{2} \mathrm{O}_{5}(\mathrm{OH})_{4} \text { (serpentine) }+\mathrm{Fe}_{3} \mathrm{O}_{4} \\
\text { (magnetite) }+4 \mathrm{H}_{2} \mathrm{O} \text { (water) }+\mathrm{H}_{2} \text { (hydrogen) }
\end{gathered}
$$




$$
\mathrm{Fe}_{3} \mathrm{Si}_{2} \mathrm{O}_{5}(\mathrm{OH})_{4} \text { (serpentine) }=\mathrm{Fe}_{3} \mathrm{O}_{4} \text { (magnetite) }+2 \mathrm{SiO}_{2} \text { (silica) }+\mathrm{H}_{2} \mathrm{O} \text { (water) }+\mathrm{H}_{2}
$$

Further reaction of silica-rich fluid with brucite leads to the formation of type II lizardite. The absence of brucite in the samples may be attributed to the dissolution of brucite during the initial stages of serpentinization. The iron from the rim of type II serpentines is consumed to precipitate magnetite in the core of type II lizardite. The depletion of $\mathrm{Ni}$ and $\mathrm{Mg}$ in type II-core suggests the removal of these elements from the core of type II lizardite. The transformation from mesh-textured type I and type II veins to the interlocking textured type III veins is due to the change in the temperature or the composition of the fluid, which leads to the recrystallization of serpentines [45].

The NiO content of type III lizardite in the bedrock is lower than type I and type II lizardite indicating a local redistribution of the element in the serpentines. It is possible that this element was transported with the serpentinizing fluid and homogenizes in the late-stage type serpentines. Type IV serpentines in the saprock are typically associated with magnetite and contain low amount of $\mathrm{NiO}$ (average $0.11 \mathrm{wt} \%$ ). Earlier work reported that magnetite is formed between 200 and $300{ }^{\circ} \mathrm{C}$ during serpentinization [46]. The composition of type IV serpentines and conditions related to its formation, suggest that these serpentines are also formed prior to the exhumation of the ultramafic body. In contrast, type $\mathrm{V}$ serpentines show the highest $\mathrm{NiO}$ content (average $1.42 \mathrm{wt} \%$ ). These serpentines are comparable to serpentine-like phases reported by previous works, which are more likely to be formed at low-temperature conditions [11,20,47].

During progressive weathering, $\mathrm{Ni}$ is leached from the limonite horizon and then transported downwards to the saprolite horizon. The leached $\mathrm{Ni}$ is accommodated in type $\mathrm{V}$ serpentines owing to the increased amount of $\mathrm{Ni}$ in these serpentines [15,48]. Therefore, the composition of type $\mathrm{V}$ serpentines indicates that it precipitated last in the paragenetic sequence. Despite type $\mathrm{V}$ serpentines only occuring in the saprock derived from clinopyroxenite, we posit that the enrichment of $\mathrm{Ni}$ in the saprolite horizon above lherzolite and harzburgite-dunite is contributed to by other minerals including goethite and talc.

Observations under the microscope show that pyroxene crystals are not only altered to serpentine but also talc. The hydration of orthopyroxene-bearing rock primarily produces talc and can be explained by the reaction below [44].

$$
3 \mathrm{MgSiO}_{3} \text { (orthopyroxene) }+\mathrm{SiO}_{2} \text { (fluid) }+\mathrm{H}_{2} \mathrm{O}=\mathrm{Mg}_{3} \mathrm{Si}_{4} \mathrm{O}_{10}(\mathrm{OH})_{2} \text { (talc) }
$$

The replacement of serpentine by talc is common in the studied bedrock. The prolonged interaction of serpentine with fluid leads to the development of talc. Since carbonates (e.g., magnesite) were not detected in the samples, this observation implies that carbonatization is not responsible for the formation of talc. Thus, talc formation (Equation (5)) is possible if the silica activity of the fluid is increased or if the water activity is decreased [49].

$$
\mathrm{Mg}_{3} \mathrm{Si}_{2} \mathrm{O}_{5}(\mathrm{OH})_{4} \text { (serpentine) }+2 \mathrm{SiO}_{2} \text { (aq.) (fluid) }=\mathrm{Mg}_{3} \mathrm{Si}_{4} \mathrm{O}_{10}(\mathrm{OH})_{2} \text { (talc) }+\mathrm{H}_{2} \mathrm{O}
$$

Talc is typically fine-grained in the bedrock samples. Based on XRPD data, talc is also present in the saprolite and limonite samples. The accumulation of talc in the weathered horizon is most likely due to residual enrichment under the supergene process. In this horizon, the $\mathrm{pH}$ is between 6.14 and 6.82 , indicating this is the right condition for the stability of talc. A number of studies have reported that talc could form under near-neutral conditions $[2,9]$ and is stable under low-temperature conditions [50].

A minor amount of goethite is present in the saprolite horizon with $\mathrm{pH}$ ranges from 7.53 to 8.13.

However, at $\mathrm{pH}$ values between 6.24 and 6.46, there is an increased amount of goethite in the limonite horizon. Goethite is the main host of $\mathrm{Ni}$ in the limonite horizon, which contains a significant amount of $\mathrm{NiO}$ of up to $1.68 \mathrm{wt} \%$. Hematite is also found in this horizon, with more hematite being 
formed when the $\mathrm{pH}$ is above $\mathrm{pH}$ 6.46. This is consistent with the fact that hematite is more stable at a $\mathrm{pH}$ closer to neutral, which is in contrast to goethite. The transformation of goethite to hematite depends mainly on temperature, the composition of goethite and the physico-chemical parameters of the solution [51,52].

Asbolane and lithiophorite-asbolane intermediate are the typical Co-bearing Mn-oxyhydroxides in the laterites from the Intex deposit in Mindoro, Philippines. Based on the XRF results, the trends of $\mathrm{Co}$ and $\mathrm{Mn}$ are similar throughout the three profiles, suggesting the strong association of Co with Mn oxyhydroxides minerals. The occurrence of these minerals is linked to the oxidation of other Mn-oxyhydroxide minerals such as buserite, cryptomelane, birnessite, hollandite, and todorokite [53,54]. However, we currently do not have definitive evidence in which primary minerals affect the formation of asbolane and lithiophorite-asbolane intermediate.

The mineral chemistry data show that both minerals contain significant amounts of CoO (up to $11.3 \mathrm{wt} \%$ ) and $\mathrm{NiO}$ (up to $15.6 \mathrm{wt} \%$ ). The sorption of $\mathrm{Ni}$ by $\mathrm{Mn}$ oxyhydroxides depends on structural and physicochemical parameters [55], and the presence of $\mathrm{Al}$ in the solution at a $\mathrm{pH}$ above 6 [56]. In this study, asbolane was found in abundance in the limonite horizon with a pH value above 7.29, whereas a lithiophorite-asbolane intermediate was found around $\mathrm{pH}$ 6.32. The results suggest that lithiophorite-asbolane intermediates form at approximately around $\mathrm{pH} 6$ and asbolane is precipitated at higher $\mathrm{pH}(\mathrm{pH}$ above 7$)$. Asbolane shows a lower $\mathrm{Co} / \mathrm{Ni}$ ratio $(0.32)$ in contrast to the lithiophorite-asbolane intermediate, which has a higher $\mathrm{Co} / \mathrm{Ni}$ ratio of 3.35. Taking into account the difference in $\mathrm{pH}$ and $\mathrm{Co} / \mathrm{Ni}$ ratio of these minerals, these results, therefore, show that under slightly acidic conditions ( $\mathrm{pH}$ 6), Co is more closely associated with a lithiophorite-asbolane intermediate.

The limonite horizon exhibits abundant silica, mainly consisting of quartz, particularly in the limonite derived from clinopyroxenite. Since pyroxenes have $15 \%$ more $\mathrm{SiO}_{2}$ than olivine, this indicates a higher amount of silica present in pyroxene-dominated rocks. The precipitation of silica is generally attributed to the poorly drained environment. Under these environmental conditions, silica may not be fully leached, resulting in its accumulation in the upper horizon [2].

\subsection{Degree of Weathering on Ultramafic Rocks and Laterites}

Two weathering indexes, namely the Ultramafic Index of Alteration (UMIA) [13,57] and the Index of Lateritization (IOL) $[57,58]$ are utilized to determine the degree of chemical weathering of ultramafic rocks and laterites in the Intex deposit. Then, the index values of this study are compared with the results from Berong deposit in Palawan, Philippines. Similarly, the Berong laterite ores are a product of the intensive weathering of ultramafic rocks under humid tropical conditions [59].

The Berong deposit in Palawan, Philippines is also divided from bottom to top into: (i) bedrock, (ii) saprolite and (iii) limonite horizon. The different horizons are classified based on Fe concentration, texture and mineralogy of the rock and laterite samples [59]. Both the studied samples from Berong and Intex deposits were acquired from topmost ridges and on uneroded areas. The bedrock in the Berong deposit is mainly peridotite (i.e., harzbugite and dunite). The summer rainfall in these two deposits is between 900 and $1800 \mathrm{~mm}$ [2]. The major differences between the two deposits are the ore minerals in the saprolite, bulk Ni concentration in the saprolite horizon and thickness of the weathered horizons. The saprolite horizon of the Berong deposit shows higher Ni contents of up to $6.11 \mathrm{wt} \%$, and the main ore minerals are talc-like (kerolite-pimelite) and sepiolite-like (sepiolite-falcondoite) phases. The profiles in the Berong deposit have thinner saprolite ( 2 to $5 \mathrm{~m}$ ) and thicker limonite (3-15 m).

The UMIA values are calculated using the equation below and are expressed in molar ratios [55]. The UMIA values of the bedrock samples from Intex deposit range from 3 to 5, the saprolite

$$
\mathrm{UMIA}=100 \times\left(\left(\mathrm{Al}_{2} \mathrm{O}_{3}+\mathrm{Fe}_{2} \mathrm{O}_{3(\mathrm{~T})}\right) /\left(\mathrm{SiO}_{2}+\mathrm{MgO}+\mathrm{Al}_{2} \mathrm{O}_{3}+\mathrm{Fe}_{2} \mathrm{O}_{3(\mathrm{~T})}\right)\right)
$$


from 3 to 14, and the limonite from 16 to 82. The low UMIA values of the bedrock and saprolite indicate that these are not intensely altered. In Figure 19a, the bedrock and saprolite have high amounts of $\mathrm{MgO}$ and $\mathrm{SiO}_{2}$. However, as weathering progresses, $\mathrm{Mg}$ and $\mathrm{Si}$ are leached from the bedrock and saprolite, resulting in an increased $\mathrm{Fe}_{2} \mathrm{O}_{3}$. The sample acquired from the transition boundary between the saprolite and limonite horizons exhibits a relatively high UMIA value of 29 compared to the bedrock and saprolite (Figure 19a). On the other hand, the limonite is characterized by higher UMIA values (more than 50), which plot near the apex of $\mathrm{Al}_{2} \mathrm{O}_{3}$ and $\mathrm{Fe}_{2} \mathrm{O}_{3}$. This observation is consistent with the fact that limonite from the Intex deposit contains high amounts of $\mathrm{Fe}_{2} \mathrm{O}_{3}$, which indicates an abundance of Fe-oxyhydroxides (e.g., goethite and hematite).

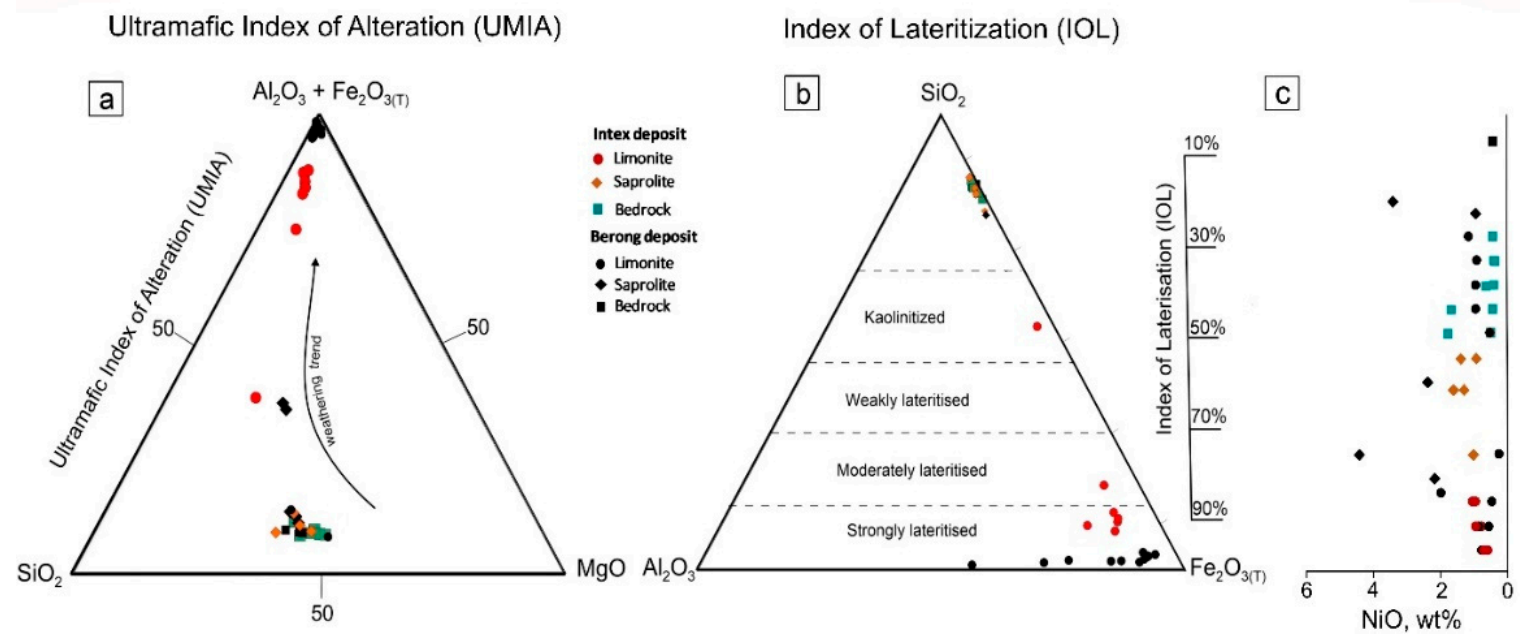

Figure 19. Molar ternary plot of (a) $\mathrm{Al}_{2} \mathrm{O}_{3}+\mathrm{Fe}_{2} \mathrm{O}_{3}+-\mathrm{SiO}_{2}-\mathrm{MgO}$ showing the weathering of ultramafic bedrock from Intex deposit with the depletion of $\mathrm{SiO}_{2}$ and $\mathrm{MgO}$ and relative enrichment of $\mathrm{Al}_{2} \mathrm{O}_{3}$ and $\mathrm{Fe}_{2} \mathrm{O}_{3}$. (b) Mass ternary plot of $\mathrm{SiO}_{2}-\mathrm{Al}_{2} \mathrm{O}_{3}-\mathrm{Fe}_{2} \mathrm{O}_{3}$ displaying the Index of Lateritization (IOL) for Intex deposit as well as the Berong deposit in Palawan, Philippines. (c) Bulk Ni contents in the bedrock and weathered horizons of the Intex and Berong deposits.

The UMIA values of the bedrock and saprolite from Intex deposit are comparable to that of the Berong deposit in Palawan, Philippines. Based on Figure 19a, the two deposits have a similar weathering trend. However, the limonite samples from the Berong deposit show the highest UMIA values, suggesting that these samples are strongly altered.

The different stages of advanced chemical weathering are not sufficiently quantified if only UMIA is utilized. To supplement these results, IOL is applied. This index is a quantitative approach to determine the stages of advanced chemical weathering (weakly, moderately, and strongly), and is typically expressed in $\mathrm{wt} \%$ [53].

$$
\mathrm{IOL}=100 \times\left(\left(\mathrm{Al}_{2} \mathrm{O}_{3}+\mathrm{Fe}_{2} \mathrm{O}_{3(\mathrm{~T})}\right) /\left(\mathrm{SiO}_{2}+\mathrm{Al}_{2} \mathrm{O}_{3}+\mathrm{Fe}_{2} \mathrm{O}_{3(\mathrm{~T})}\right)\right)
$$

The IOL values of the bedrock are in the range of 14 to 19 , and the saprolite up to 17 . However, the limonite from Intex deposit exhibits higher IOL values, reaching up to 94 (Figure 19b). Earlier studies reported that unweathered ultramafic rocks have IOL values of less than 40 [46]. Even though the IOL values of the saprolite are low, weak weathering was observed under the microscope. Conversely, the sample from the transition boundary has a higher IOL value (46), corresponding to the point in the middle section of the $\mathrm{SiO}_{2}-\mathrm{Al}_{2} \mathrm{O}_{3}-\mathrm{Fe}_{2} \mathrm{O}_{3}$ (SAF) ternary diagram, which indicates a significant loss of silica (Figure 19b). As lateritization progresses, more silica is leached, resulting in the relative enrichment of Fe. Samples from the saprolite and limonite horizons show an apparent increase in $\mathrm{Ni}$ (Figure 19c). 
The calculated IOL values of the Intex profiles correspond to a less advanced stage of weathering or moderately to strongly "laterized" profiles, which leads to the development of thicker saprolite (3-8 $\mathrm{m}$ ) and thinner limonite (3-4.5 m). In contrast, the profiles in the Berong deposit experienced a more advanced stage of weathering or strongly "laterized" profiles and subsequently yielded thinner saprolite (2-5 m) and thicker limonite (3-15 m). Concerning the Ni contents between the two deposits, the Intex deposit exhibit lower bulk $\mathrm{Ni}$ in the saprolite (up to $1.69 \mathrm{wt} \%$ ) and limonite (up to $0.79 \mathrm{wt} \%$ ) compared with the Berong deposit (up to $6.11 \mathrm{wt} \%$; up to $0.90 \mathrm{wt} \%$ ) (Figure 19c). Thus, the difference in Ni concentration between the Intex and Berong deposits may be the result of different degrees of weathering of the laterites.

Since the limonite from the Intex deposit experienced a less advanced degree of weathering, this affected the leaching and re-mobilization of $\mathrm{Ni}$ from the limonite horizon towards the saprolite horizon. The weathering solution is not supersaturated with $\mathrm{Ni}, \mathrm{Si}$, and $\mathrm{Mg}$, which may have resulted in the poor precipitation of talc-like (kerolite-pimelite) or sepiolite-like (sepiolite-falcondoite) phases in the studied saprolite horizon. Nevertheless, the combined mineralogical and geochemical data suggest that $\mathrm{Ni}$ in the Intex deposit has undergone supergene enrichment similar to other humid tropical laterite deposits in New Caledonia, the Caribbean, and northeastern Australia $[3,11,13,17]$.

\section{Conclusions}

The weathering of the serpentinized ultramafic rocks resulted in the formation of the Intex laterite deposit. In the bedrock, olivine is the main source of ore in the saprolite and limonite horizons. The early stages of serpentinization lead to the development of type I, type II, type III, and type IV serpentines. The results of this study show that these serpentines are of hydrothermal origin. The late-stage type $V$ serpentines cut the early-stage type I to type IV serpentines. Type V serpentines are the serpentine-like garnierites and display the highest amount of $\mathrm{NiO}$ (average $1.42 \mathrm{wt} \%$ ).

The UMIA and IOL values of the Intex laterites are in agreement with the less advanced stage of weathering compared with Berong laterites. The difference in bulk Ni concentration between the Intex and Berong deposits may be the result of different degrees of weathering of the laterites. The less extreme degree of weathering of Intex profiles indicates less advanced leaching, and thus the re-distribution of $\mathrm{Ni}, \mathrm{Si}$, and $\mathrm{Mg}$ from the limonite towards the saprolite horizon may have resulted in the poor precipitation of talc-like (kerolite-pimelite) and sepiolite-like (sepiolite-falcondoite) phases in the studied saprolite horizon.

Supergene enrichment of $\mathrm{Ni}$ occurred in the Intex laterite deposit, which is comparable to the $\mathrm{Ni}$ laterite deposits in New Caledonia, the Caribbean, and northeastern Australia. The main difference between the Intex deposit and other tropical laterite deposits is the composition of garnierites. In this study, garnierites consist mainly of serpentine-like minerals, whereas talc-like and sepiolite-like phases are often found in other laterite deposits. Another similarity of the studied deposit with other classic deposits is the occurrence of goethite and Mn-oxyhydroxides (i.e., asbolane and lithiophorite-asbolane intermediate) in the limonite horizon. Nickel is mainly hosted by goethite, and Mn-oxyhydroxides contain significant amounts of $\mathrm{CoO}$ (up to $11.3 \mathrm{wt} \%$ ) and $\mathrm{NiO}$ (up to $15.6 \mathrm{wt} \%$ ).

Author Contributions: C.A.J.T. acquired the samples, performed the analyses, prepared, and revised the manuscript. Y.W. supervised, visualized and contributed significantly to interpret the data and review the manuscript. K.S. supervised and assisted in performing the XRF and EPMA analyses. T.E. supervised and helped obtain good quality Raman data. C.A. acquired the resources needed for the fieldwork. C.F. helped conceptualize the research which resulted in the preparation of the manuscript. All authors have read and agreed to the published version of the manuscript.

Funding: This research received no external funding.

Acknowledgments: We acknowledge the support of Intex Resources Philippines Inc. for the approval of the field investigation. The authors are thankful to Carolyn Sacdalan for her assistance during the acquisition of samples. This work is not possible without the financial support of the Leading Program of Akita University. We highly appreciate the support of Nobukazu Soma and his staff from the Mineral Resources Research Group of the Geological Survey of Japan, National Institute of Geological Sciences during the preparation and analysis of samples by X-ray fluorescence analysis and electron probe microanalysis. 
Conflicts of Interest: The authors declare no conflict of interests.

\section{References}

1. Trescases, J.J. The lateritic nickel-ore deposits. In Soils and Sediments Mineralogy and Geochemistry; Paquet, H., Clauer, N., Eds.; Springer: Berlin, Germany, 1997; pp. 125-138.

2. Butt, C.R.M.; Cluzel, D. Nickel laterite ore deposits: Weathered serpentinites. Elements 2013, 9, $123-128$. [CrossRef]

3. Chassé, M.; Griffin, W.L.; O'Reilly, S.Y.; Calas, G. Scandium speciation in a world-class lateritic deposit. Geochem. Perspect. Lett. 2017, 3, 105-113. [CrossRef]

4. Teitler, Y.; Cathelineau, M.; Ulrich, M.; Ambrosi, J.P.; Munoz, M.; Sevin, B. Petrology and geochemistry of scandium in New Caledonian Ni-Co laterites. J. Geochem. Explor. 2019, 196, 131-155. [CrossRef]

5. Elias, M. Nickel laterite deposits-Geological overview, resources, and exploitation. In Giant Ore Deposits: Characteristics, Genesis and Exploration; Special Publication; CODES, University of Tasmania: Hobart, TAS, Australia, 2002; Volume 4, pp. 205-220.

6. Golightly, J.P. Nickeliferous laterite deposits. In Economic Geology 75th (Seventy-Fifth) Anniversary Volume 1905-1980; Economic Geology Publishing Company: New Haven, CT, USA, 1981; Volume 75, pp. 710-735.

7. Brand, N.W.; Butt, C.R.M.; Elias, M. Nickel laterites: Classification and features. AGSO J. Aust. Geol. Geophys. 1998, 17, 81-88.

8. Freyssinet, P.; Butt, C.R.M.; Morris, R.C.; Piantone, P. Ore-Forming Processes Related to Lateritic Weathering. 100th Anniversary Volume; Society of Economic Geologists: Littleton, CO, USA, 2005; pp. 681-722.

9. Gleeson, S.A.; Herrington, R.J.; Durango, J.; Velásquez, C.A.; Koll, G. The mineralogy and geochemistry of the Cerro Matoso S.A. Ni Laterite deposit, Montelíbano, Colombia. Econ. Geol. 2004, 99, 1197-1213. [CrossRef]

10. Marsh, E.; Anderson, E.; Gray, F. Ni-Co Laterites-A Deposit Model; US Geological Survey: Reston, VA, USA, 2011; pp. 1-9.

11. Villanova-de-Benavent, C.; Proenza, J.A.; Galí, S.; García-Casco, A.; Tauler, E.; Lewis, J.F.; Longo, F. Garnierites and garnierites: Textures, mineralogy, and geochemistry of garnierites in the Falcondo Ni-laterite deposit, Dominican Republic. Ore Geol. Rev. 2014, 58, 91-109. [CrossRef]

12. Putzolu, F.; Balassone, G.; Boni, M.; Maczurad, M.; Mondillo, N.; Najorka, J.; Pirajno, F. Mineralogical Association and Ni-Co deportment in the Wingellina oxide-type laterite deposit (Western Australia). Ore Geol. Rev. 2018, 196, 282-296. [CrossRef]

13. Aiglsperger, T.; Proenza, J.A.; Lewis, J.F.; Labrador, M.; Svojtka, M.; Rojas-Puron, A.; Ďurišová, J. Critical metals (REE, Sc, PGE) in Ni laterites from Cuba and the Dominican Republic. Ore Geol Rev. 2016, 73, 127-147. [CrossRef]

14. Roqué-Rosell, J.; Mosselman, J.F.W.; Proenza, J.A.; Labrador, M.; Gali, S.; Atkinson, K.D.; Quinn, P.D. Sorption of Ni by'lithiophorite-asbolane' intermediates in Moa Bay lateritic deposits, eastern Cuba. Chem. Geol. 2010, 275, 9-18. [CrossRef]

15. Dublet, G.; Juillot, F.; Morin, G.; Fritsch, E.; Fandeur, D.; Brown, G.E. Goethite aging explains Ni depletion in upper units of ultramafic lateritic ores from New Caledonia. Geochim. Cosmochim. Acta 2015, 160, 1-15. [CrossRef]

16. Myagkiy, A.; Truche, L.; Cathelineau, M.; Golfier, F. Revealing the conditions of Ni mineralization in the laterite profiles of New Caledonia: Insights from reactive geochemical transport modelling. Chem. Geol. 2017, 466, 274-284. [CrossRef]

17. Cluzel, D.; Vigier, B. Syntectonic mobility of supergene nickel ores of New Caledonia (Southwest Pacific). Evidence from garnierite veins and faulted regolith. Resour. Geol. 2008, 58, 161-170. [CrossRef]

18. Villanova-de-Benavent, C.; Domènech, C.; Tauler, E.; Galí, S.; Tassara, S.; Proenza, J.A. Fe-Ni-bearing serpentines from the saprolite horizon of Caribbean Ni-laterite deposits: New insights from thermodynamic calculations. Miner. Deposita 2017, 52, 979-992. [CrossRef]

19. Fritsch, E.; Juillot, F.; Dublet, G.; Fonteneau, L.; Fandeur, D.; Martin, E.; Caner, L.; Auzende, A.L.; Grauby, O.; Beaufort, D. An alternative model for the formation of hydrous $\mathrm{Mg} / \mathrm{Ni}$ layer silicates ("deweylite"/"garnierite") in faulted peridotites of New Caledonia: I. Texture and mineralogy of a paragenetic succession of silicate infillings. Eur. J. Miner. 2016, 28, 295-311. [CrossRef] 
20. Muñoz, M.; Ulrich, M.; Cathelineau, M.; Mathon, O. Weathering processes and crystal chemistry of Ni-bearing minerals in saprock horizons of New Caledonia ophiolite. J. Geochem. Explor. 2019, 198, 82-99. [CrossRef]

21. Hamilton, W. Tectonics of the Indonesian Region; US Government Printing Office: Washington, DC, USA, 1979; Volume 1078, p. 345.

22. Holloway, N.H. North Palawan block, Philippines-Its relation to Asian mainland and role in evolution of South China Sea. Am. Assoc. Pet. Geol. Bull. 1982, 14, 19-58. [CrossRef]

23. Rangin, C.; Stephan, J.F.; Müller, C. Middle Oligocene oceanic crust of South China Sea jammed into Mindoro collision zone (Philippines). Geology 1985, 13, 425-428. [CrossRef]

24. Bird, P.R.; Quinton, N.A.; Beeson, M.N.; Bristow, C. Mindoro: A rifted microcontinent in collision with the Philippine Island arc: Basin evolution and hydrocarbon potential. J. Southeast Asian Earth Sci. 1993, 8, 449-468. [CrossRef]

25. Karig, D.E. Plate convergence between the Philippines and the Ryukyu islands. Marine Geol. 1973, 14, 153-168. [CrossRef]

26. Mitchell, A.H.G.; Hernandez, F.; dela Cruz, A.P. Cenozoic evolution of the Philippine archipelago. J. Southeast Asian Earth Sci. 1986, 1, 3-22. [CrossRef]

27. Sarewitz, D.R.; Karig, D.E. Stratigraphic framework of western Mindoro Island, Philippines. J. Geol. Soc. Philipp. 1986, 40, 3-51.

28. Hashimoto, W.; Sato, T. Contribution to the geology of Mindoro and neighboring islands, the Philippines. Geol. Paleontol. Southeast Asia 1968, 5, 192-210.

29. Karig, D.E.; Sarewitz, D.R. Processes of allochthonous terrane evolution, Mindoro, Island, Philippines. Tectonics 1986, 5, 525-552.

30. Yumul, G.P., Jr.; Dimalanta, C.B.; Tamayo, R.A., Jr.; Maury, R.C. Collision, subduction and accretion events in the Philippines: A synthesis. Island Arc 2003, 12, 77-91. [CrossRef]

31. Yumul, G.P.; Dimalanta, C.B.; Tamayo, R.A. Indenter-tectonics in the Philippines: Example from the Palawan Microcontinental Block-Philippine mobile belt collision. Resour. Geol. 2005, 55, 189-198. [CrossRef]

32. Faure, M.; Marchadier, Y.; Rangin, C. Pre-Eocene Synmetamorphic Structure in the Mindoro-Romblon-Palawan Area, West Philippines, and implications for the history of Southeast Asia. Tectonics 1989, 8, 963-979. [CrossRef]

33. Concepcion, R.A.B.; Dimalanta, C.B.; Yumul, G.P.; Faustino-Eslava, D.V.; Queaňo, K.L.; Tamayo, R.A.; Imai, A. Petrography, geochemistry, and tectonics of a rifted fragment of Mainland Asia: Evidence from the Lasala Formation, Mindoro Island, Philippines. Int. J. Earth Sci. 2012, 101, 273-290. [CrossRef]

34. Zamoras, L.R.; Matsuoka, A. Accretion and postaccretion tectonics of the Calamian Islands, North Palawan block, Philippines. Island Arc 2004, 13, 506-519. [CrossRef]

35. Canto, A.P.B.; Padrones, J.T.; Concepcion, R.A.B.; Perez, A.D.C.; Tamayo, R.A.; Dimalanta, C.B.; Faustino-Eslava, D.V.; Queaño, K.L.; Yumul, G.P. Geology of northwestern Mindoro and its offshore islands: Implications for terrane accretion in west Central Philippines. J. Asian Earth Sci. 2012, 61, $78-87$. [CrossRef]

36. Petersen, J.S.; Jensen, S.M.; Blomsterberg, J.; Audet, M.A. 'Mineral Resources of the Mindoro Nickel-Laterite Project, the Philippines: NI 43-101 Technical Report'. 2010. Available online: http://www.intexresources.com/ _upl/a1.0_-_43-101technical_report_-_geology_-_2010-02-11 (accessed on 18 September 2019).

37. Auzende, A.L.; Devouard, B.; Guillot, S.; Daniel, I.; Baronnet, A.; Lardeaux, J.M. 465 Serpentinites from Central Cuba: Petrology, and HRTEM study. Eur. J. Mineral. 2002, 14, 905-914. [CrossRef]

38. Petriglieri, J.R.; Salvioli-Mariani, E.; Mantovani, L.; Tribaudino, M.; Lottici, P.P.; Laporte-Magoni, C.; Bersani, D. Micro-Raman mapping of the polymorphs of serpentine. J. Raman Spectrosc. 2015, 46, 953-958. [CrossRef]

39. Ferrer, C. Laterites from Different Ultramafic Rocks in Mindoro, Philippines: Effect of Bedrock Mineralogy on the Mineralogy and Geochemistry of Laterites. Master's Thesis, UP Diliman, Quezon City, Philippines, 2013; pp. 41-47.

40. Schwartz, S.; Guillot, S.; Reynard, B.; Lafay, R.; Debret, B.; Nicollet, C.; Lanari, P.; Auzende, A.L. Pressure-temperature estimates of the lizardite/antigorite transition in high pressure serpentinites. Lithos 2013, 178, 197-210. [CrossRef]

41. Auzende, A.L.; Daniel, I.; Reynard, B.; Lemaire, C.; Guyot, F. High-pressure behaviour of serpentine minerals: A Raman spectroscopic study. Phys. Chem. Miner. 2004, 31, 269-277. [CrossRef] 
42. Toft, P.B.; Arkani-Hamed, J.; Haggerty, S.E. The effects of serpentinization on density and magnetic susceptibility: A petrophysical model. Phys. Earth Planet Int. 1990, 65, 137-157. [CrossRef]

43. Beard, J.S.; Frost, B.R.; Fryer, P.; McCaig, A.; Searle, R.; Ildefonse, B.; Zinin, P.; Sharma, S.K. Onset and progression of serpentinization and magnetite formation in Olivine-rich troctolite from IODP hole U1309D. J. Petrol. 2009, 50, 387-403. [CrossRef]

44. Frost, B.R.; Beard, J.S. On silica activity and serpentinization. J. Petrol. 2007, 48, 1351-1368. [CrossRef]

45. O'Hanley, D.S. Serpentinites: Records of Tectonic and Petrological History; Oxford University Press on Demand: Oxford, UK, 1996; Volume 1, pp. 42-58.

46. Klein, F.; Bach, W.; Humphris, S.E.; Kahl, W.A.; Jöns, N.; Moskowitz, B.; Berquó, T.S. Magnetite in seafloor serpentinite-Some like it hot. Geology 2014, 42, 135-138. [CrossRef]

47. Tauler, E.; Proenza, J.A.; Gali, S.; Lewis, J.F.; Labrador, M.; García-Romero, E.; Bloise, G. Ni-sepiolite-falcondoite in garnierite mineralization from the Falcondo Ni-laterite deposit, Dominican Republic. Clay Miner. 2009, 44, 435-454. [CrossRef]

48. Trescases, J.J. Weathering and geochemical behavior of the elements of ultramafic rocks in New Caledonia. Bur. Miner. Resour. Geol. Geophys. Canberra Extract Bull. 1973, 141, 149-161.

49. Bach, W.; Garrido, C.J.; Paulick, H.; Harvey, J.; Rosner, M. Seawater-peridotite interactions: First insights from ODP Leg 209, MAR 15 N. Geochem. Geophys. 2004, 5, 1-22. [CrossRef]

50. Bricker, O.P.; Wayne, N.H.; Gunter, W.D. The stability of talc. Am. Miner. 1973, 58, 64-72.

51. Schwertmann, U.; Murad, E. Effect of $\mathrm{pH}$ on the formation of goethite and hematite from ferrihydrite. Clays Clay Miner. 1983, 31, 277-284. [CrossRef]

52. Gualtieri, A.F.; Venturelli, P. In situ study of the goethite-hematite phase transformation by real time synchrotron powder diffraction. Am. Miner. 1999, 84, 895-904. [CrossRef]

53. Taylor, R.M.; McKenzie, R.M.; Norrish, K. The mineralogy and chemistry of manganese in some Australian soils. Aust. J. Soil Res. 1964, 2, 235-248. [CrossRef]

54. McKenzie, R.M. Manganese oxides and hydroxides. In Minerals in Soil Environment; Dixon, J.B., Weed, S.B., Eds.; SSSA: Madison, WI, USA, 1989; pp. 439-465.

55. Peacock, C.L. Physiochemical controls on the crystal-chemistry of Ni in birnessite: Genetic implications for ferromanganese precipitates. Geochim. Cosmochim. Acta 2009, 73, 3568-3578. [CrossRef]

56. Roberts, D.R.; Scheidegger, A.M.; Sparks, D.L. Kinetics of mixed Ni-Al precipitate formation on a soil clay fraction. Environ. Sci. Technol. 1999, 33, 3749-3754. [CrossRef]

57. Babechuk, M.G.; Widdowson, M.; Kamber, B.S. Quantifying chemical weathering intensity and trace element release from two contrasting basalt profiles, Deccan Traps, India. Chem. Geol. 2014, 363, 56-75. [CrossRef]

58. Rivera, J.; Reich, M.; Schoenberg, R.; González-Jiménez, J.M.; Barra, F.; Aiglsperger, T.; Carretier, S. Platinum-group element and gold enrichment in soils monitored by chromium stable isotopes during weathering of ultramafic rocks. Chem. Geol. 2018, 499, 84-99. [CrossRef]

59. Tupaz, C.A.J.; Watanabe, Y.; Sanematsu, K.; Echigo, T. Mineralogy and Geochemistry of the Berong Ni-Co Laterite Deposit, Palawan, Philippines; Elsevier: Amsterdam, The Netherlands, 2019.

(C) 2020 by the authors. Licensee MDPI, Basel, Switzerland. This article is an open access article distributed under the terms and conditions of the Creative Commons Attribution (CC BY) license (http://creativecommons.org/licenses/by/4.0/). 